\title{
Effects on aquatic ecosystems
}

\author{
D.-P. Häder ${ }^{\text {a,* }}$, H.D. Kumar ${ }^{\text {b }}$, R.C. Smith ${ }^{\text {c }}$, R.C. Worrest ${ }^{\text {d }}$ \\ ${ }^{a}$ Institut für Botanik und Pharmazeutische Biologie der Universität Erlangen-Nürnburg, Staudtstraße 5, D-91058 Erlangen, Germany \\ ${ }^{\mathrm{b}}$ Center of Advanced Study in Botany, Banaras Hindu University, 214, Saketnagar Colony, PO Box 5014, Varanasi 221005, India \\ ${ }^{\mathrm{c}}$ Institute for Computational Earth System Science (ICESS) and Department of Geography, University of California, Santa Barbara, CA 93106, USA \\ ${ }^{\mathrm{d}}$ CIESIN, Columbia University, 1747 Pennsylvania Avenue, NW, Suite 200, Washington, DC 20006, USA
}

\begin{abstract}
Regarding the effects of UV-B radiation on aquatic ecosystems, recent scientific and public interest has focused on marine primary producers and on the aquatic web, which has resulted in a multitude of studies indicating mostly detrimental effects of UV-B radiation on aquatic organisms. The interest has expanded to include ecologically significant groups and major biomass producers using mesocosm studies, emphasizing species interactions. This paper assesses the effects of UV-B radiation on dissolved organic matter, decomposers, primary and secondary producers, and briefly summarizes recent studies in freshwater and marine systems.

Dissolved organic carbon (DOC) and particulate organic carbon (POC) are degradation products of living organisms. These substances are of importance in the cycling of carbon in aquatic ecosystems. UV-B radiation has been found to break down high-molecular-weight substances and make them available to bacterial degradation. In addition, DOC is responsible for short-wavelength absorption in the water column. Especially in coastal areas and freshwater ecosystems, penetration of solar radiation is limited by high concentrations of dissolved and particulate matter. On the other hand, climate warming and acidification result in faster degradation of these substances and thus enhance the penetration of UV radiation into the water column.

Several research groups have investigated light penetration into the water column. Past studies on UV penetration into the water column were based on temporally and spatially scattered measurements. The process of spectral attenuation of radiant energy in natural waters is well understood and straightforward to model. Less known is the spatial and temporal variability of in-water optical properties influencing UV attenuation and there are few long-term observations. In Europe, this deficiency of measurements is being corrected by a project involving the development of a monitoring system (ELDONET) for solar radiation using three-channel dosimeters (UV-A, UV-B, PAR) that are being installed from Abisko (North Sweden, $68^{\circ} \mathrm{N}, 19^{\circ} \mathrm{E}$ ) to Tenerife (Canary Islands, $27^{\circ} \mathrm{N}, 17^{\circ} \mathrm{W}$ ). Some of the instruments have been installed in the water column (North Sea, Baltic Sea, Kattegat, East and Western Mediterranean, North Atlantic), establishing the first network of underwater dosimeters for continuous monitoring.

Bacteria play a vital role in mineralization of organic matter and provide a trophic link to higher organisms. New techniques have substantially changed our perception of the role of bacteria in aquatic ecosystems over the recent past and bacterioplankton productivity is far greater than previously thought, having high division and turnover rates. It has been shown that bacterioplankton play a central role in the carbon flux in aquatic ecosystems by taking up DOC and remineralizing the carbon. Bacterioplankton are more prone to UV-B stress than larger eukaryotic organisms and, based on one study, produce about double the amount of cyclobutane dimers. Recently, the mechanism of nitrogen fixation by cyanobacteria has been shown to be affected by UV-B stress. Wetlands constitute important ecosystems both in the tropics and at temperate latitudes. In these areas, cyanobacteria form major constituents in microbial mats. The organisms optimize their position in the community by vertical migration in the mat, which is controlled by both visible and UV-B radiation. Cyanobacteria are also important in tropical and sub-tropical rice paddy fields, where they contribute significantly to the availability of nitrogen. Solar UV radiation affects growth, development and several physiological responses of these organisms.

On a global basis, phytoplankton are the most important biomass producers in aquatic ecosystems. The organisms populate the top layers of the oceans and freshwater habitats where they receive sufficient solar radiation for photosynthetic processes. New research strengthens previous evidence that solar UV affects growth and reproduction, photosynthetic energy-harvesting enzymes and other cellular proteins, as well as photosynthetic pigment contents. The uptake of ammonium and nitrate is affected by solar radiation in phytoplankton, as well as in macroalgae. Damage to phytoplankton at the molecular, cellular, population and community levels has been demonstrated. In contrast, at the ecosystem level there are few convincing data with respect to the effects of ozone-related UV-B increases and considerable uncertainty remains. Following UV-B irradiation, shifts in phytoplankton community structure have been demonstrated, which may have consequences for the food web.
\end{abstract}

*Corresponding author. Tel.: 49-9131-8528-216; Fax: 49-9131-8528-215; E-mail: dphaeder@biologie.uni-erlangen.de 
Macroalgae and seagrasses are important biomass producers in aquatic ecosystems (but considerably smaller than phytoplankton). In contrast to phytoplankton, most of these organisms are sessile and can thus not avoid exposure to solar radiation at their growth site. Recent investigations showed a pronounced sensitivity to solar UV-B radiation, and effects have been found throughout the top 10-15 m of the water column. Photoinhibition can be quantified by oxygen exchange or by PAM (pulse amplitude modulated) fluorescence. Surface-adapted macroalgae, such as several brown and green algae, show a maximum of oxygen production at or close to the surface; whereas algae adapted to lower irradiances usually thrive best when exposed deeper in the water column. Mechanisms of protection and repair are being investigated.

UV effects on aquatic animals are of increased interest. Evidence for UV effects has been demonstrated in zooplankton activity. Other UVB-sensitive aquatic organisms include sea urchins, corals and amphibians. Solar UV radiation has been known to affect corals directly. In addition, photosynthesis in their symbiotic algae is impaired, resulting in reduced organic carbon supply. Amphibian populations are in serious decline in many areas of the world, and scientists are seeking explanations for this phenomenon. Most amphibian population declines are probably due to habitat destruction or habitat alteration. Some declines are probably the result of natural population fluctuations. Other explanations for the population declines and reductions in range include disease, pollution, atmospheric changes and introduced competitors and predators. UV-B radiation is one agent that may act in conjunction with other stresses to affect amphibian populations adversely.

The succession of algal communities is controlled by a complex array of external conditions, stress factors and interspecies influences. Freshwater ecosystems have a high turnover and the success of an individual species is difficult to predict, but the development of general patterns of community structure follows defined routes. There is a strong predictive relationship between DOC concentration and the depth to which UV radiation penetrates in lakes. Since DOC varies widely, freshwater systems display a wide range of sensitivity to UV penetration. In these systems, increased solar UV-B radiation is an additional stress factor that may change species composition and biomass productivity.

The Arctic aquatic ecosystem is one of the most productive ecosystems on earth and is a source of fish and crustaceans for human consumption. Both endemic and migratory species breed and reproduce in this ocean in spring and early summer, at a time when recorded increases in UV-B radiation are maximal. Productivity in the Arctic ocean has been reported to be higher and more heterogeneous than in the Antarctic ocean. In the Bering Sea, the sea-edge communities contribute about 40-50\% of the total productivity. Because of the shallow water and the prominent stratification of the water layer, the phytoplankton are more exposed and affected by solar UV-B radiation. In addition, many economically important fish (e.g., herring, pollock, cod and salmon) spawn in shallow waters where they are exposed to increased solar UV-B radiation. Many of the eggs and early larval stages are found at or near the surface. Consequently, reduced productivity of fish and other marine crops is possible but has not been demonstrated.

There is increased consensus, covering a wide range of aquatic ecosystems, that environmental UV-B, independent of ozone-related increases, is an important ecological stress that influences the growth, survival and distribution of phytoplankton. Polar ecosystems, where ozone-related UV-B increases are the greatest and which are globally significant ecosystems, are of particular concern. However, these ecosystems are characterized by large spatial and temporal variability, which makes it difficult to separate out UV-B-specific effects on single species or whole phytoplankton communities. There is clear evidence for short-term effects. In one study a 4-23\% photoinhibition of photosystem II activity was measured under the ozone hole. However, extrapolation of short-term effects to long-term ecological consequences requires various complex effects to be accounted for and quantitative evaluation remains uncertain. C 1998 UNEP. Published by Elsevier Science S.A. All rights reserved.

Keywords: Aquatic ecosystems; Ultraviolet-B radiation; Dissolved organic carbon; Bakterioplankton; Phytoplankton; Zooplankton; Macroalgae; Seagrass

\section{Introduction}

Solar short-wavelength radiation has been shown to reach ecologically significant depths in many freshwater and marine ecosystems [1-6]. Drastic stratospheric ozone depletion over both the Antarctic and Arctic, as well as moderate decreases in total ozone column over high- and mid-latitude waters, have been reported. There is strong evidence that these trends increase the amount of solar UV-B radiation that penetrates within the euphotic zone, where phytoplankton productivity takes place. In addition, there is evidence that ozone depletion alters the UV-B:UV-A:PAR (photosynthetically active radiation) ratio, which may impair the delicate light-dependent responses of aquatic organisms, including photosynthesis, photo-orientation, photoinhibition and photoprotection [2,7-11]. Changes in the spectral composition exceeding those experienced during the evolution of exposed organisms may pose significant stress for the diverse aquatic ecosystems [12]. Both UV-B and UV-A radiation affect the growth and productivity by a number of mechanisms involving several molecular targets within the exposed cells. While most organisms possess effective protective and repair mechanisms, excessive exposure to solar UV radiation may overload their capabilities.

Significant changes of solar UV radiation on aquatic ecosystems may result in decreased biomass productivity. The impact of this decrease would be reflected through all levels of the intricate food web, resulting in reduced food production for humans $[7,13,14]$, reduced sink capacity for atmospheric carbon dioxide [15-17], as well as changes in species composition and ecosystem integrity. The role of oceanic carbon dioxide uptake in global warming is of high significance $[18,19]$. However, the potential impact of ozone depletion on atmospheric carbon dioxide, mediated through inhibition of marine primary production, is uncertain and a more rigorous and detailed analysis is urgently needed. Research has been intensified over the last few decades to evaluate UV-Brelated damage of aquatic ecosystems [20]. Important 
reviews on various aspects of UV effects on aquatic ecosystems include: aquatic ecosystes in general [14,21]; the role of mycosporine-like amino acids (MAAs) in marine organisms [22]; phytoplankton [10,23,24]; macroalgae [25,26]; corals and coral bleaching $[27,28]$; lake acidification and UV penetration $[29,162]$.

\section{Dissolved organic matter and solar UV radiation}

Solar UV radiation has been shown to degrade dissolved organic carbon (DOC) photolytically, most of the DOC being of terrestrial origin and relatively resistant to other forces [30]. Humic substances are fairly resistant to bacterial degradation, but after photolytic activity the products (e.g., formaldehyde, acetaldehyde, glyoxylate and pyruvate) are readily taken up by bacterioplankton [31]. Humic substances strongly absorb UV radiation. Thus, increased breakdown of DOC and subsequent consumption by bacteria increases the UV-B penetration into the water column. Close to the surface, solar UV radiation inhibits bacterioplankton activity and rapidly photolyses DOC. However, the uptake of the fragments is hampered by the inhibition of the bacterial ectoenzymes. Only when both bacteria and the photolysed DOC circulate to deeper layers does the uptake rate increase. Another aspect of DOC photolysis is the generation of photosensitizers, which upon absorption of UV radiation produce reactive oxygen species (ROS) or free radicals. Dimethyl sulfide is released from the water at a rate that is closely correlated with the concentration of DOC [32]. Dimethylsulfoniopropionate is considered an osmoregulator in phytoplankton.

\section{Measurements and modelling}

To determine the effects of solar radiation on marine ecosystems, the penetration of UV and PAR into the water column needs to be measured [33,34]. Marine waters show large temporal and regional differences in their concentrations of dissolved and particulate absorbing substances. Jerlov [35] classified marine waters into nine types of coastal and five types of open-ocean waters depending on their transmission. The ratio between the $0.1 \%$ depths for UV-B and PAR can be used to calculate the detrimental effects on algae by solar UV-B radiation that hits the organisms in the euphotic zone [36]. Recent developments allow an accurate measurement of the underwater light field [37]. Yellow substances, chlorophyll $a$ and other photosynthetic pigments, as well as organic and inorganic particulate material mainly cause the spectral attenuation of UV-B radiation in the water column. The modulation of the open-ocean underwater light field by phytoplankton has been extensively studied [38], but reports on the underwater light field in coastal habitats colonized by macroalgae are scarce, particularly in the UV-B range. Algal canopies modify the light quality by absorption and scattering of the incident light.
Recently, a network of dosimeters (ELDONET) was installed in Europe ranging from Abisko in Northern Sweden to Gran Canaria with a total of 26 instruments [39]. Two of the instruments are located at high altitudes and six are located under water where they operate in conjunction with a terrestrial counterpart (Fig. 1). These instruments record solar radiation fully automatically in three channels (UV-B, UVA, PAR). The data are transmitted to a server in Pisa and are available to the public on the Internet in graphical and numerical form (http:// power.ib.pi.cnr.it:80/eldonet/). Other networks have been installed, e.g., Biospherical Instruments (San Diego, CA) is responsible for obtaining and distributing irradiance data from the US National Science Foundation UV Spectroradiometer Monitoring Network (http://www. biospherical.com). Data are available from stations in San Diego (CA), Ushuaia (Argentina), Barrow (AK) and three Antarctic stations ( South Pole, Palmer and McMurdo). Great care is necessary to guarantee quality control of the light measurements [40].

Underwater UV irradiance has been measured at northern latitudes $\left(79^{\circ} \mathrm{N}\right.$, Spitsbergen, Norway). The measurements showed significant short-term increases due to local ozone holes over those reported in winter 1994-1995 in the European SESAME campaign (Second European Stratospheric Arctic and Midlatitude Experiment), in which a depletion of 20-30\% of the stratospheric ozone was observed [41].

Another approach to quantifying the underwater light climate is modelling [42]. Within limits, the optical characteristics of the water column can be obtained from satellite data (e.g., CZCS and SeaWiFS, Fig. 2). These instruments cover only the visible range, but attempts have been and are being made to extrapolate the data into the UV range so as to make these remotely sensed data relevent to UV studies.

There have been great efforts to develop techniques for measuring algal biomass by using remote sensors. Most work has focused on quantifying chlorophyll from phytoplankton in surface oceanic waters [43]. Piazena and Häder [36] discussed the applicability of remote sensing to detecting and quantifying phytoplankton in the water. One major obstacle for remote monitoring is the fact that overflying instruments mainly determine the surface signal. Therefore, profound knowledge of the vertical distribution of phytoplankton as well as the distribution of algal groups is necessary to derive a quantitative analysis of biomass productivity [36]. Mooring of optical instruments has been used to determine phytoplankton production in the oligotrophic waters of the Sargasso Sea [44]. Meinesz et al. [45] have studied macroalgal biomass and distribution on the bottom of clear waters in Polynesia.

Recently Behrenfeld and Falkowski [46] have evaluated models used to estimate photosynthetic rates derived from satellite-based chlorophyll concentration measurements. In addition, they [47] have evaluated various primary productivity models, provided a classification scheme for these productivity models and show that many of these, apparently different, models show fundamental synonymy. If equivalent 


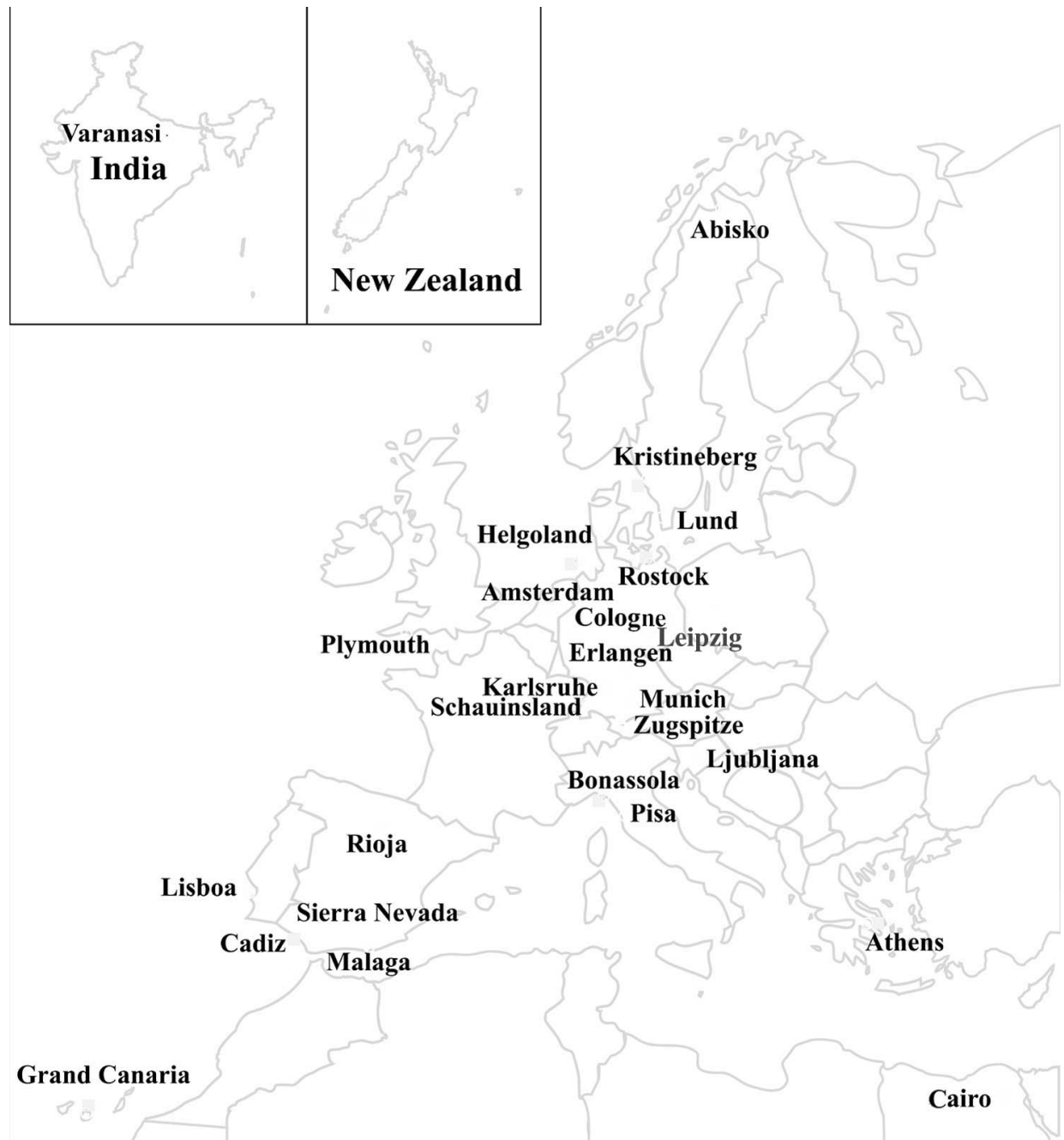

Fig. 1. Locations of the terrestrial, aquatic and high-altitude instruments in the ELDONET network of solar dosimeters: circles, terrestrial instruments; squares, underwater instruments; triangles, high-altitude instruments.

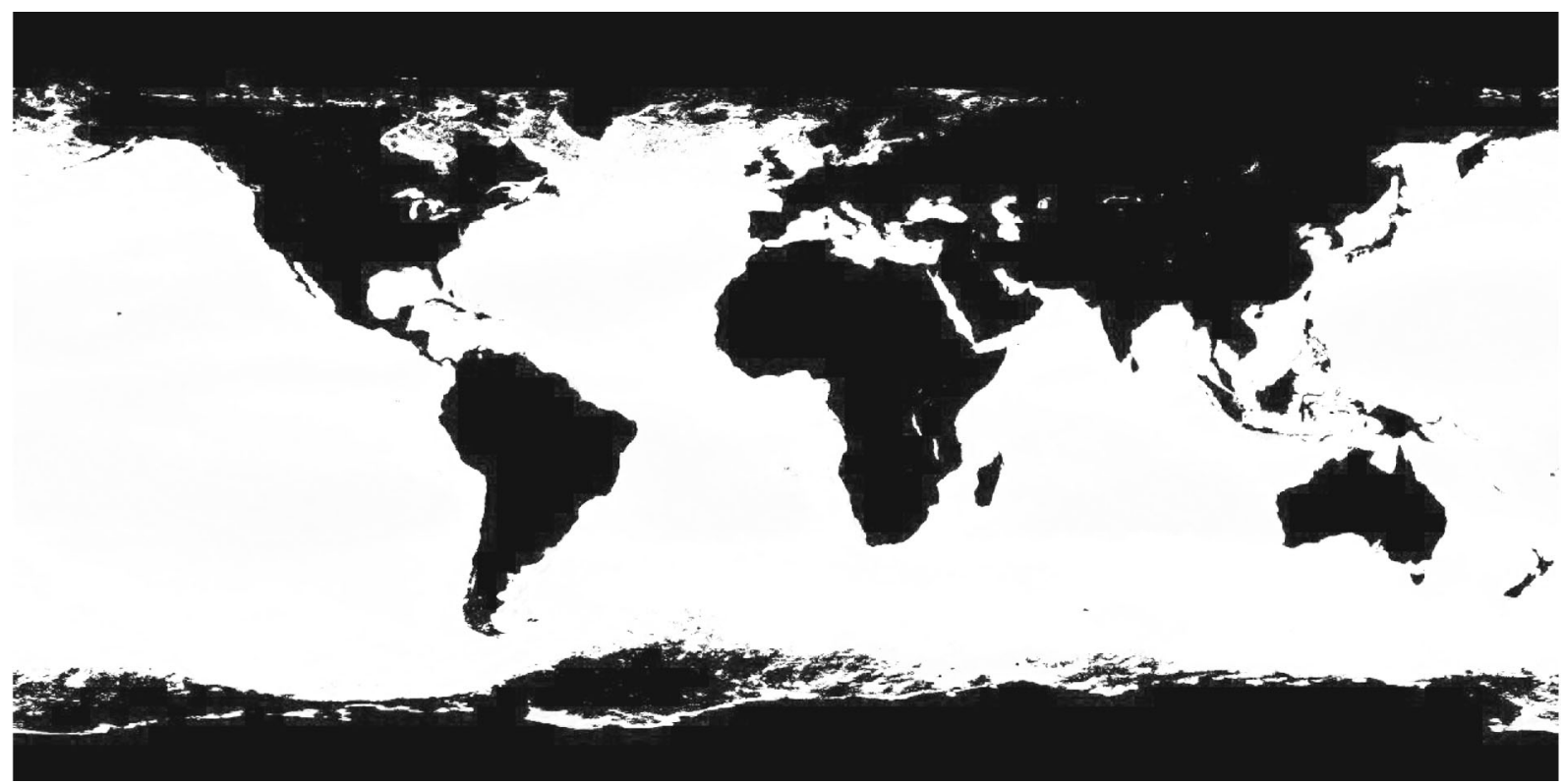

Fig. 2. Chlorophyll concentration in the ocean. Provided by the SeaWiFS Project, NASA/Goddard Space Flight Center. 
parameterizations are used for satellite-derived chlorophyll measurments and the maximum chlorophyll-specific carbon fixation rate, then estimates of global annual primary production were found to be due primarily to these variables.

\section{Bacterioplankton and picoplankton}

Use of modern epifluorescence microscopy techniques has substantially changed our perception of the role of bacteria in aquatic ecosystems over the recent past. Bacterioplankton productivity is far greater than previously thought, having high division and turnover rates [48]. The productivity is comparable to or exceeds phytoplankton primary productivity [32]. Bacterioplankton are no longer regarded solely as final decomposers of organic material (Fig. 3). According to the 'microbial loop hypothesis', bacterioplankton are seen in the centre of a food web, having a similar function to phytoplankton and protists [49]. It has been shown that bacterioplankton play a central role in the carbon flux in aquatic ecosystems by taking up DOC and remineralizing the carbon.

The effect of solar UV on bacterioplankton depends on the spectral attenuation coefficients in the water column and the time pattern of exposure and protection for the organisms as they are passively moved in the mixing layer. Bacterioplankton seem to lack UV-screening pigments such as mycosporines or scytonemins, possibly because of their small size [50,51]. As a consequence, bacterioplankton are more prone to UV-B stress than larger eukaryotic organisms and exposure produces about double the amount of cyclobutane dimers as shown in a case study in the Gulf of Mexico [52,53]. This damage is at least partially offset by photoreactivation [54]. The equilibrium between UV damage and photorepair is governed by the passive movement of the cells within the mixing layer, where they are alternately exposed to high levels of damaging solar UV radiation near the surface and beneficial UV-A/blue light at greater depths. Other macromolecular components of the bacterial cells, as well as ectoenzymes responsible for the cleavage of external organic matter, are affected by solar UV-B radiation [55]. The bacterioplankton

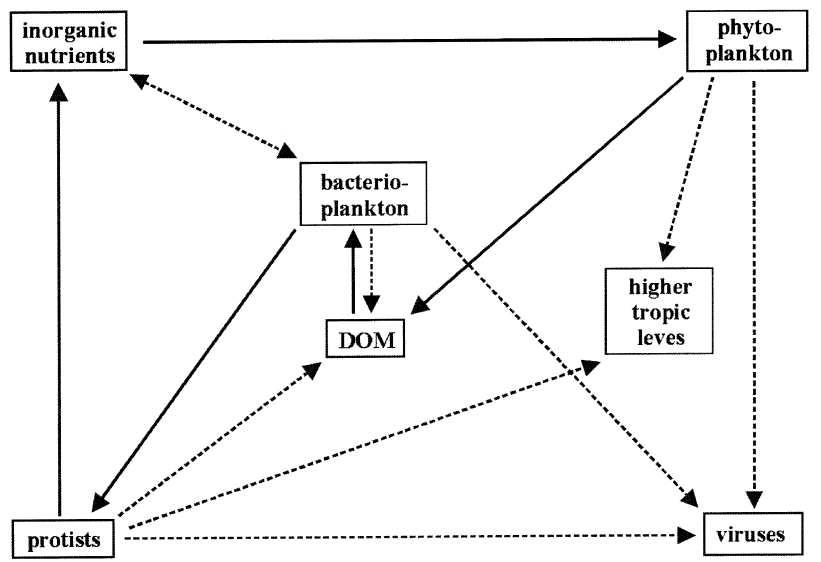

Fig. 3. Microbial loop (continuous arrows) in an aquatic habitat. serve as food for heterotrophic flagellate picoplankton $(<1$ $\mu \mathrm{m})$. The bacterial plankton population is limited by UV damage, viruses and heterotrophic flagellates [56,57]. This effect is partially offset by an effective repair mechanism using the photolyase enzyme. UV/blue radiation (360-430 $\mathrm{nm}$ ) is most effective in the induction of the activity. It should also be mentioned that the viruses and nanoflagellates show a high sensitivity to solar UV radiation [58].

\section{Cyanobacteria}

Cyanobacteria are a group of prokaryotes that possess a higher plant-type oxygenic photosynthesis. In addition to being key players in aquatic productivity, several of these organisms are capable of fixing atmospheric nitrogen either as free-living organisms or in symbiosis with many other species including protists, animals and plants [59]. They use the enzyme nitrogenase to reduce atmospheric nitrogen into ammonium ions $\left(\mathrm{NH}_{4}{ }^{+}\right)$, which they make available for aquatic eukaryotic phytoplankton as well as higher plants [60-63]. The agricultural potential of cyanobacteria as a biological fertilizer for wet soils, such as in rice paddies [64], has been recognized. Cyanobacteria are cosmopolitan and must possess a high potential of adaptation to diverse environmental factors. However, UV-B is known to affect processes such as growth, survival, pigmentation and motility, as well as the enzymes of nitrogen metabolism and $\mathrm{CO}_{2}$ fixation $[65,66]$. Depending on the species, growth and survival decrease within a few hours of UV-B irradiation. Cyanobacteria also fix atmospheric nitrogen in mid-latitude agricultural systems, though not as massively as in paddy rice fields; therefore UV-B effects on these organisms could also be relevant on a global scale.

In addition to DNA, which is a highly susceptible cellular target, the photosynthetic pigments are also affected. The phycobiliproteins, especially, are readily bleached and cleaved $[61,67,68]$. Bleaching of these accessory pigments is far more efficient than that of chlorophyll $a$ or carotenoids [67]. At lower doses the energy transfer to the reaction centre of photosystem II is impaired [61]. Simultaneously with destruction, an increased synthesis of phycobiliproteins has been observed under mild UV-B stress. The fact that these pigments strongly absorb in the UV-B range and that they form a peripheral layer around the sensitive central part containing the DNA might indicate that phycobilins are effective screening pigments, as well [68]. They are capable of intercepting more than $99 \%$ of UV-B radiation before it penetrates to the genetic material.

UV-B-induced inhibition of photosynthetic activity has been demonstrated in a number of marine and freshwater cyanobacteria. Sinha et al. [61] reported that, in addition to the bleaching of the photosynthetic pigments, RuBisCO (ribulose-1,5-bis-phosphate carboxylase/oxygenase) activity was severely affected by UV-B treatment. Ammonium 
uptake was reduced by $10 \%$ in cultures exposed to solar radiation.

The nitrogen-fixing enzyme nitrogenase is inhibited by UV-B even after a few minutes of in vivo exposure. A complete loss of activity was found within 35-55 min depending upon the species [69]. The inactivation may possibly be due to the inhibition of ATP synthesis by UV-B. In contrast to the effect on nitrogenase, a stimulation of nitrate reductase by UV-B was found in all nitrogen-fixing cyanobacterial strains studied so far [67], while the ammonia-assimilating enzyme glutamine synthetase (GS) is inhibited.

Many cyanobacteria have developed a number of adaptive strategies to reduce the negative effects of excessive radiation, including the avoidance of brightly irradiated habitats, the synthesis of UV-screening pigments and the production of chemical scavengers that detoxify the highly reactive oxidants produced photochemically [70]. Screening pigments include scytonemin and MAAs, as well as a number of spectroscopically characterized but chemically unidentified water-soluble pigments (e.g., a brown-colored pigment from Scytonema hofmanii and a pink extract from Nostoc spongiaeforme) [69,71]. Cyanobacteria such as Scytonema and Nostoc form filaments that are embedded in a mucilaginous sheath. The screening pigment from Scytonema hofmannii shows an absorption maximum at $314 \mathrm{~nm}$ and is released into the medium during the late stationary phase of growth. These organisms are more tolerant of UV-B irradiation than those that do not contain such covering [67]. For example, other species of Scytonema that do not produce this pigment are unable to survive $2 \mathrm{~h}$ of UV-B irradiation $\left(2.5 \mathrm{~W} \mathrm{~m}^{-2}\right)$. Karsten and Garcia-Pichel [72] showed that screening pigments such as scytonemins, carotenoids and MAAs are incorporated into the cytoplasm or the outer slime sheath, efficiently protecting the organisms from solar short-wavelength radiation.

\section{Phytoplankton}

Considerable recent work, covering a wide range of aquatic ecosystems, has contributed to an increased consensus that environmental UV-B, independent of ozone-related increases, is an important ecological stress that influences the growth, survival and distributions of phytoplankton. On a global scale, phytoplankton are the most important biomass producers in aquatic ecosystems. The organisms populate the top layers of the oceans and freshwater habitats where they receive sufficient solar radiation (photosynthetic available radiation, PAR) for photosynthetic processes. This layer is called the euphotic zone, the base of which is defined as the depth where gross daily photosynthetic carbon fixation balances phytoplankton respiratory losses over a day (typically a depth to which $1-0.1 \%$ of PAR penetrates). Within this zone, phytoplankton are simultaneously exposed to solar UV radiation, in addition to longer-wavelength radiation. Information required to estimate quantitatively ozone-related UV-
B damage to phytoplankton include: the spectral characteristics of solar radiation penetrating to depth and its spacetime variability; a biological weighting function (BWF) of the biological effect; an exposure-response curve (ERC); a quantitative model of phytoplankton inhibition by UV-B; and an assessment of how vertical mixing influences variable irradiance exposures of phytoplankton and their physiological response. We are far from a full quantitative understanding, but advances in each of these areas have been made during the past few years and recent reviews include Refs. $[21,23,24,73,74]$.

While it has long been known that DOC influences the penetration of UV-B radiation, recent work has provided quantitative data that permit a more accurate estimated of DOC breakdown by UV-B, the resultant reduction of absorption in the UV region, and consequent increased penetration to depth. Among other things, this recent work permits a more accurate estimation of the penetration of UV-B to depth based upon knowledge of in-water DOC concentrations. This may be especially important in assessing the potential influence of increased UV-B on freshwater ecosystems.

BWFs describing the spectrally weighted sensitivity of phytoplankton photosynthesis to UV and visible irradiance, have recently been determined by a number of workers [7577]. There is general agreement that the biological weighting, while highest in the UV-B, also contains a significant UV-A component. However, in spite of this broad agreement, BWFs have been shown to vary by species, region, mixing characteristics of the water column and, perhaps, other environmental variability. As a consequence, it is now recognized that a single, or even a few, BWFs may be inadequate for a complete description of an ecosystem, thus making quantitative analysis more complex.

ERCs [23,24,75] have recently been determined. To estimate the ERC one must determine if the measured damage is a function solely of cumulative exposure or whether it is a function of exposure rate. As noted by these authors, this difference is fundamental, and it has an important impact on both the design and interpretation of experiments and on the extrapolation of experimental results to real-world predictions. Further, the shape of the ERC influences model accuracy. In addition, the ERC, which is important for accurate modelling, shows a range of experimental variability [77], probably dependent on the balance between damage and repair and, thus, on the time-scale considered. Recent work has shown two forms of ERC in phytoplankton from different hydrographic environments, thus making accurate modelling of ozone-related impacts more complex.

Models have been developed [23,76-79] in an effort to estimate the impact of ozone depletion. These efforts represent important advances in our effort to quantify possible impacts, identifying the most significant processes and unknowns and evaluating uncertainities. However, these recent advances continue to underscore the difficulty of using short-term observations to estimate longer-term (days to years) ecological response [2,70,77,79-81]. 
Solar UV affects growth and reproduction, photosynthetic energy-harvesting enzymes [82-88] and other cellular proteins, as well as photosynthetic pigment contents $[10,89$ 92]. The uptake of ammonium and nitrate is affected by solar radiation in phytoplankton [93-96], as well as in macroalgae [97]. Phytoplankton respond with the production of heatshock proteins, as well as changes in the cellular amino acid pools. One of the major targets is the DNA, which strongly absorbs in the short-wavelength range of solar radiation. Solar UV-B has been found to induce DNA damage and DNA synthesis delay in many organisms [98-101]. UV-B effects have also been studied on the ecosystem level using mesocosms [102,103].

\section{Macroalgae and seagrasses}

While phytoplankton are motile in the water column [7], most macroalgae are sessile and therefore restricted to their growth site [104]. Macroalgae show a distinct and fixed pattern of vertical distribution in their habitat. Some of these plants inhabit the supralittoral (coast above the high-water mark) exposed only to the spray from the surf, whereas others populate the eulittoral (intertidal zone), which is characterized by the regular temporal change in the tides [105]. Still others are never exposed to air, since they are restricted to the sublittoral zone. The range in exposure can be substantial, from over $1000 \mathrm{~W} \mathrm{~m}^{-2}$ (total solar radiation) at the surface to less than $0.01 \%$ of that which reaches the understorey of a kelp habitat [106]. Macroalgae have developed mechanisms to regulate their photosynthetic activity to adapt to the changing light regime and protect themselves from excessive radiation [25]. They use the same mechanism of photoinhibition as higher plants to decrease the photosynthetic electron transport during periods of excessive radiation. This phenomenon facilitates thermal dissipation of excessive excitation. Different algal species occupy different depth niches and are adapted to different solar exposure [26]. They also differ in their ability to cope with enhanced UV radiation [107]. A broad survey was carried out to understand photosynthesis in aquatic ecosystems and the different adaptation strategies to solar radiation of ecologically important species of green, red and brown algae from the North Sea, Baltic Sea, Mediterranean, Atlantic, polar and tropical oceans [26,106,108-113] .

Photoinhibition can be quantified by oxygen exchange [114] or by PAM (pulse amplitude modulated) fluorescence measurements developed by Schreiber et al. [115] and based on transient changes of chlorophyll fluorescence. Surfaceadapted macroalgae, such as several brown (Cystoseira, Padina, Fucus) and green algae (Ulva, Enteromorpha) show a maximum of oxygen production at or close to the surface $[26,116]$; whereas algae adapted to lower irradiances usually thrive best when exposed deeper in the water column (the green algae Cladophora, Caulerpa, most red algae) [26]. It is interesting to note that respiration is inhibited to a far smaller degree than photosynthesis.

PAM fluorescence allows the determination of the photochemical and non-photochemical quenching [117]. Recently, an underwater PAM instrument was developed for in situ measurement of the quantum yield of fluorescence, which promises advances in the knowledge on ecophysiology of macroalgae. The increase in non-photochemical quenching is related to the violaxanthin cycle, which is believed to quench excess excitation energy both in algae and in higher plants [26,118]. Even algae harvested from rock pools, where they are exposed to extreme irradiances, show signs of photoinhibition after extended periods of exposure (Fig. 4). Deep-water algae and those adapted to shaded conditions are inhibited even faster when exposed to direct solar radiation. Large differences were also found in the recovery

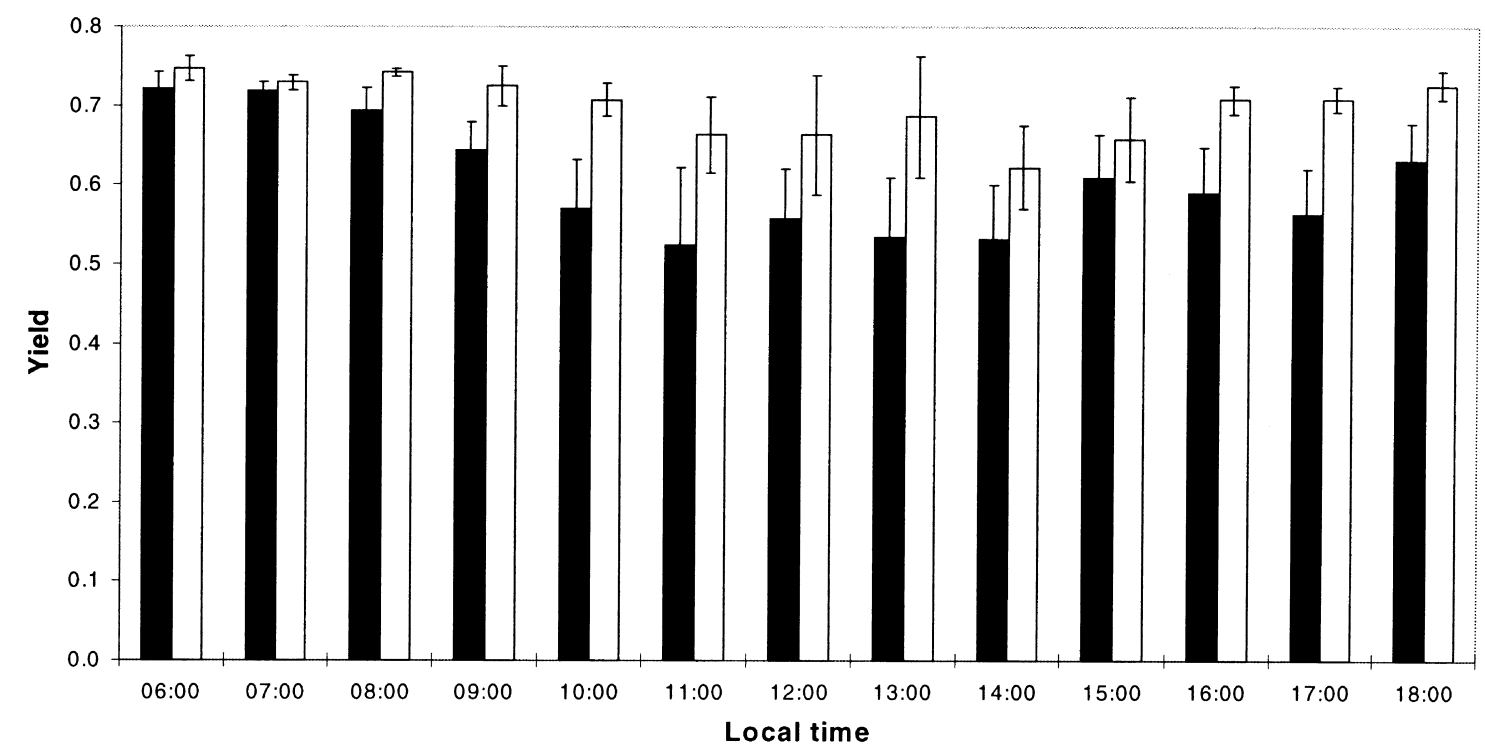

Fig. 4. Photosynthetic quantum yield measured on site using a PAM fluorimeter in the Mediterranean brown alga Padina pavonica harvested from $0 \mathrm{~m}$ (closed bars) and $6 \mathrm{~m}$ depth (open bars) at $1 \mathrm{~h}$ intervals [20]. 
between high light-adapted and protected species. A considerable proportion of photoinhibition is due to PAR (400-700 $\mathrm{nm})$. Exclusion studies were carried out to determine the effects of solar UV-B and UV-A radiation [83]. Increasing exposure to solar radiation resulted in a shift of the compensation point to higher irradiances. The compensation point defines the irradiance at which photosynthetic oxygen production and respiratory oxygen consumption balance each other. Exclusion of UV-B partially reduced the effects. This trend increased when about half or all of the UV-A radiation was excluded (Schott filters WG 360 and 395).

Chronic photoinhibition occurs when algae are exposed to excessive irradiance. The inhibition is characterized by photodamage of PS II reaction centres and subsequent proteolysis of the D1 protein [119]. In contrast, dynamic photoinhibition is readily reversible and follows a diurnal pattern with the lowest quantum yield around or soon after noon [26,120]. The lowest light compensation point for photosynthesis has been reported in Arctic and Antarctic algae [121-123].

The long-term effects of solar UV on the primary productivity of macroalgae still need to be evaluated. Shallow-water specimens in coral reefs undergo a 50\% reduction in photosynthetic efficiency during the middle of the day and show a complete recovery by late afternoon. Both UV-A and UV-B cause depression of the photosynthetic rate in the brown alga Laminaria digitata [124].

Recently, different methods for measuring light absorption in macroalgae have been compared [125]. The absorption determined by using an integrating sphere and by the opalglass technique in a spectrophotometer in thin macroalgae was intercalibrated. García-Pichel [126] has developed a scalar irradiance fibre-optic microprobe for the measurement of ultraviolet radiation at high spatial resolution.

The photoprotective mechanism of the xanthophyll cycle has been investigated mostly in microalgae [127] and to less extent in macroalgae, e.g., the green alga Ulva lactuca [128] and the brown algae Dictyota dichotoma [129] and Lobophora variegata [130]. Red algae did not show the xanthophyll cycle.

Another mechanism for protection against UV radiation (UV-A and UV-B) is the production of screening pigments such as carotenoids or UV-absorbing MAAs (Table 1). MAAs have been found in green, red and brown algae from tropical, temperate and polar regions. Since these substances are chemically very stable, they accumulate in the sediment of lakes and can be used of a permanent record for past ultraviolet radiation environments [131]. In tropical algae, enhanced levels of carotenoids and UV-absorbing compounds were detected in tissues from the canopy compared to tissues from understorey locations in turf-forming rhodophytes $[110,111]$. Current research indicates that solar UV$\mathrm{B}$ is a stress factor for macroalgae and seagrasses even at current levels; therefore further increases in UV-B may reduce biomass production and changes in species composition in macroalgae ecosystems.

\section{Zooplankton}

Phytoplankton concentrations depend not only on nutrient availability, light, temperature and UV stress but also strongly on the grazing losses due to zooplankton activity [132]. The zooplankton communities in turn not only depend on phytoplankton availability but also on grazing pressure as well as solar UV and temperature. Even at current levels, solar UV$\mathrm{B}$ radiation can be a limiting factor, and small increases in UV-B exposure could result in significant reductions in the size of the consumer community $[133,134]$. However, variability in cloud cover, water quality and vertical distribution and displacement within the water column can all have an impact on the magnitude of the UV-B effect. Also, related to temperature effects, the macrozooplankton biomass in the California Current has decreased by $80 \%$ since 1951 due to climatic warming by more than $1.5^{\circ} \mathrm{C}$ in some places [135]. As in phytoplankton, UV-B-induced DNA damage and photoenzymatic DNA repair have also been demonstrated in zooplankton [136]. In planktonic embryos of copepods photoreactivation of UV-induced damage was found to be an efficient repair mechanism [137]. However, UV severely affects survival, fecundity and sex ratio in several intertidal copepods, while others remained largely unaffected [138].

\section{Secondary consumers}

Other UV-B sensitive marine organisms include sea urchins and corals [27,140]. However, many organisms

Table 1

Structure, absorption maximum and retention time (HPLC) of some common mycosporines [139]

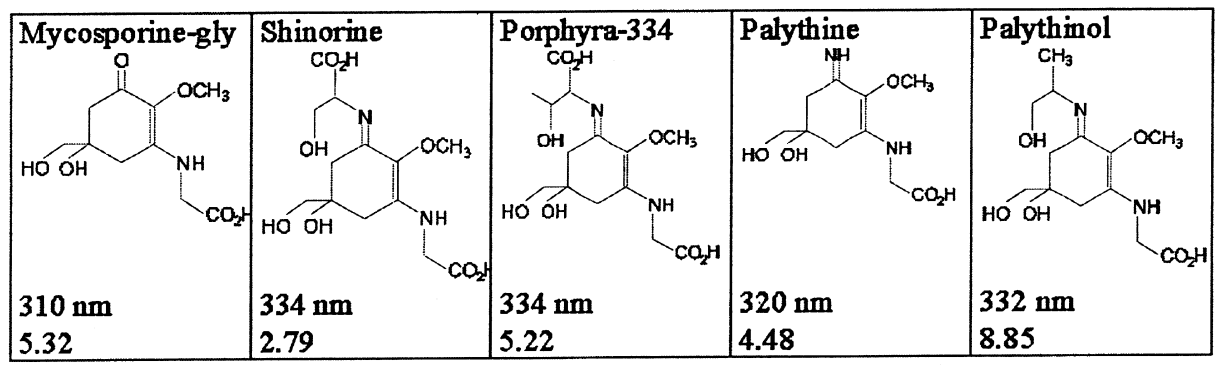


seem to have adapted to solar UV by different strategies. For example, the planula larvae of the coral Agaricia agaricites show a pronounced variation in UV-B sensitivity along a depth gradient [141] and the green sea urchin Strongylocentrotus droebachiensis uses MAAs that it derives from its diet for UV absorption. This latter adaptation was determined by feeding an MAA-rich red alga, Mastocarpus stellatus, and an MAA-deficient brown alga, Laminaria saccharina, to sea urchins [142].

Although humans use about $8 \%$ of the productivity of the oceans, that fraction increases to more than $25 \%$ for upwelling areas and to $35 \%$ for temperate continental shelf systems [143]. For about one-sixth of the world's population (primarily developing nations), the oceans provide more than one-third of their animal protein [144]. Many of the fisheries that depend upon the oceanic primary productivity are unsustainable. Although the primary causes for a decline in fish populations are predation and poor food supply for larvae, overfishing of adults, water temperature, pollution and disease $[145,146]$, exposure to increased UV-B radiation may contribute to that decline. The eggs and larvae of many fish are sensitive to UV-B exposure [147-149]. However, imprecisely defined habitat characteristics and the unknown effect of small increases in UV-B exposure on the naturally high mortality rates of fish larvae are major barriers to a more accurate assessment of ozone depletion on marine fish populations. Actual in-lake experiments have demonstrated that ambient UV levels in the surface waters of temperate lakes are adequate to induce $100 \%$ mortality of yellow perch eggs in low-DOC lakes but not in lakes with higher DOC levels [150].

Amphibian populations are in serious decline in many areas of the world [151], and scientists are seeking explanations for this phenomenon [152,153]. Worrest and Kimeldorf [154] noted several adverse effects of increased exposure to UV-B radiation on the systemic development of boreal toad (Bufo boreas boreas) tadpoles in the laboratory. They questioned whether an increased exposure to UV-B radiation in nature could have an adverse impact on amphibian development. Vetter and colleagues (submitted for publication), using a newly developed chemiluminescent immunoblot assay capable of measuring thymine-thymine pyrimidine dimers (TT dimers) in DNA, have investigated DNA damage and repair in pelagic fish eggs and larvae. Since the typical method of thymine dimer repair is photoenzymatic repair, the observed amount of DNA damage at any time of day is the net result of damage rates and repair rates. They find that over a day the typical diel pattern of DNA damage, at least for northern anchovy, resembles a dose-rate meter rather than a cumulative dose meter, i.e., DNA damage increases as the sun rises, reaches a peak level of damage near solar noon, and is followed by a period of rapid repair in the afternoon when UV-B is decreasing but the visible light utilized for repair is still abundant. An understanding of this diel cycle of damage and repair is essential for the correct interpretation of relationships between solar irradiance and levels of DNA damage in field samples.

As reported by several authors [155-159], field studies in which amphibian embryos were exposed to natural sunlight or to sunlight with UV-B radiation removed have shown conflicting results. Some studies resulted in increased embryonic mortality after UV-B exposure, whereas others show that current levels of UV-B radiation are not detrimental. Abiotic factors, such as water depth, water colour and dissolved organic content at the egg-laying sites, effectively reduce UV-B penetration through the water and reduce exposure to UV-B radiation at all life-history stages. Biotic factors, such as jelly capsules around eggs, melanin pigmentation of eggs and colour of larvae and metamorphosed forms, further reduce the effectiveness of UV-B penetration.

Most amphibian population declines are probably due to habitat destruction or habitat alteration. Some declines are probably the result of natural population fluctuations. Other explanations for the population declines and reductions in range include disease, pollution, atmospheric changes and introduced competitors and predators. UV-B radiation is one agent that may act in conjunction with other stresses to affect amphibian populations adversely.

\section{Ecosystems}

\subsection{Freshwater}

The succession of periphytic and limnic algal communities is controlled by a complex array of external conditions, stress factors and interspecies influences [160]. Freshwater ecosystems have a high turnover and the success of an individual species is difficult to predict, but the development of general patterns of community structure follows defined routes [161]. Even though transparency for solar UV-B is considerably lower than in oceanic waters, increased solar UV-B is an additional stress factor which may change species composition and biomass productivity [29,36,162,163]. The interaction of UV-B and heavy-metal concentrations resulted in synergistic inhibition of nutrient uptake, enzyme activity, carbon fixation, ATP synthesis and oxygen evolution in a number of phytoplankton species [160,164]. 67 freshwater species of algae (Chlorophyta and Chromophyta) were screened in an experiment to determine their UV-B sensitivity [165]. The algae were selected to represent different ecosystems ranging from high-altitude lakes to thermal springs. The most sensitive species lost 30-50\% of their oxygen-evolving capacity during a $2 \mathrm{~h}$ UV-B exposure $\left(2 \mathrm{~W} \mathrm{~m}^{-2}\right)$. Many UV-B-resistant species were found in high mountain locations. They often have solid cell walls encrusted with sporopollenin. In another experiment the effects of solar UV$\mathrm{B}$ on growth and species composition were studied in an exclusion experiment in a high-altitude mountain lake [166] . In this study no significant differences were found between the control (full sunlight) and the UV-B-depleted enclosure. 
However, it should be mentioned that UV-A also has been found to affect growth and photosynthesis [167]. In other organisms UV-A had a beneficial effect, partially counteracting UV-B inhibition [168]. In addition to the primary producers, the significance of heterotrophic picoplankton in freshwater ecosystems needs to be taken into account [169].

The results of an experiment by Bothwell et al. [80] reinforce the view that predictions of responses by ecosystems to elevated UV-B exposure should not be based solely on singlespecies assessments. As reported, greater algal growth occurred in an artificial stream under UV-B exposure than in the control, after some lag time. The explanation of this surprising (at that time) result was that the grazers, larval chironomids, were more sensitive to UV-B radiation than their food, the algae.

\subsection{The Antarctic aquatic ecosystem}

Productivity in the Southern Ocean is characterized by large-scale spatial and temporal variability $[78,170,171]$. This makes it difficult to filter out UV-B-specific effects from other variable environmental effects [77], or to estimate the impact on single species or whole phytoplankton communities $[172,173]$. Especially at high latitudes, variability in solar elevation, cloud cover, deep vertical mixing and the cover of ice and snow significantly confound field results of UV-B effects on phytoplankton and the consequent interpretation of these results. With increasingly complete observations, recent estimates of the effect of $50 \%$ ozone reduction on integral water column productivity are relatively consistent, less than 5\% [76] and 0.7-8.5\% (depending on BWF, assumed mixing regime and cloudiness [174]), with earlier estimates $(6 \%,[2])$.

Observations by many workers, which vary greatly in both time and space, show convincing evidence of UV-B damage to phytoplankton, but in order to determine long-term effects, acclimation and adaptation phenomena $[28,175,176]$ as well as other factors [77] need to be assessed. Several models have been developed [76-78,177] to permit estimation of ecosystem productivity loss based on short-term observations. While it has long been known that vertical mixing is a major complication in attempting to quantify UV-B effects on phytoplankton, only recently have the interactive effects of ozone depletion and vertical mixing on photosynthesis of Antarctic phytoplankton been modelled [77]. Field results of these workers [174], in agreement with others $[2,178,179]$, clearly demonstrate that photosynthesis of Antarctic phytoplankton is inhibited by ambient UV during incubation in fixed containers. The difficulty comes in the generalization of these experimental results to Antarctic waters where mixing significantly alters the exposure of phytoplankton to UV-B. To estimate this environmental influence, Neale and coworkers [77] have developed a model of UV-influenced phytoplankton during vertical mixing. They find that near-surface UV strongly inhibits photosynthesis under all modelled conditions and that inhibition of photo- synthesis can be enhanced or decreased by vertical mixing, dependent upon the depth of the mixed layer. Further, they show that an abrupt 50\% reduction in stratospheric ozone could, as a worst case, lower daily integrated water column photosynthesis by as much as $8.5 \%$. Note that this modelling result is consistent with the results of Smith [2] and coworkers, who specifically targeted the marginal ice zone (MIZ), where meltwater provides stability and minimizes vertical mixing, for their studies. However, Neale and coworkers also note that inhibition associated with realistic environmental variability can have a stronger influence on integrated water column photosynthesis than UV-B effects: vertical mixing by about $\pm 37 \%$, measured variable sensitivity of phytoplankton to UV by about $\pm 46 \%$ and cloudiness by about $\pm 15 \%$. These workers conclude "that ozone depletion can inhibit primary productivity in open waters of the Antarctic, but that natural variability in exposures of phytoplankton to UV, associated with vertical mixing and cloud cover, has a major role in either enhancing or diminishing the impact on water column photosynthesis". They also note that "regardless of these natural interactions, UV is a significant environmental stressor, and its effects are enhanced by ozone depletion" [77].

\subsection{The Arctic aquatic ecosystem}

Though being in a similar situation of increasing UV-B stress as the Antarctic aquatic ecosystems, the Arctic differs in many respects from its antipode [180,181]. The Arctic ocean is a nearly closed water mass with limited water exchange with the Atlantic and Pacific oceans. It represents $25 \%$ of the global continental shelf and receives about $10 \%$ of the world river discharge. This considerable freshwater inflow causes pronounced stratification year round and is responsible for high concentrations of POC and DOC, which strongly affect the penetration of solar UV into the water column. The plumes of major rivers can be traced several hundred kilometres [182]. Another difference between the Arctic and the Antarctic is the greater importance of macroalgae in the Arctic. The Arctic aquatic ecosystem is one of the most productive ecosystems on earth and is a source of fish and crustaceans for human consumption. Both endemic and migratory species breed and reproduce in this ocean in spring and early summer, at a time when recorded increases in UV$\mathrm{B}$ radiation are maximal. Productivity in the Arctic ocean has been reported to be higher and more heterogeneous than in the Antarctic ocean [183]. In the Bering Sea, the sea-edge communities contribute about $40-50 \%$ of the total productivity. Because of the shallow water and the prominent stratification of the water layer, the phytoplankton may experience relatively high levels of solar UV-B. In addition, many economically important fish (e.g., herring, pollock, cod and salmon) spawn in shallow waters where they are exposed to this increased solar UV-B radiation when ozone is depleted. Many of the eggs and early larval stages are found at or near the surface. It is possible, given the general relationships 
between primary and fish production, that reduced productivity of fish and other marine crops would affect not only humans in the region but also natural predators (otters, seals, foxes, ice bears). However, further careful analysis is necessary to quantify UV-B-related phytoplankton inhibitation and possible effects on the flow of energy to higher trophic levels. Currently we cannot accurately estimate if ozonerelated impacts will, or will not, influence fish and other important marine crops.

The high concentrations of humic substances, which tend to be strong absorbers of UV-B radiation, may alter the underwater light penetration significantly [181]. On the other hand, UV-B is known to attack humic substances photochemically, altering the absorptive nature of the water column and leading to faster uptake by bacteria and heterotrophic nanoflagellates [181]. The problem is more complicated and not well understood since UV-B has been found to be more detrimental for small phytoplankton organisms [50] and even more so for the bacterioplankton [32]. In contrast, a recent study of size-fractionated phytoplankton in a lake indicated that cells larger than $2 \mu \mathrm{m}$ were twice as sensitive to solar UV-B as smaller cells [184]. The Arctic ocean is often nutrient limited, especially with respect to the inorganic nutrients such as nitrogen and phosphorus. The nitrogen cycle governs the primary productivity of the marine ecosystems. The same is true for the oligotrophic lakes and streams. Nitrogen and phosphorus uptake are UV-B sensitive [185], which may augment the UV-B sensitivity of Arctic phytoplankton communities. Low doses of UV-B increase the uptake of phosphate, which is probably used for DNA repair, while it impairs the uptake at higher doses. All these effects have an impact on the biogeochemical cycles.

\section{Conclusions and consequences}

Potential consequences of enhanced levels of exposure to UV-B radiation include loss of biomass, such as food sources for humans; changes in species composition; decrease in availability of nitrogen compounds; and reduced uptake capacity for atmospheric carbon dioxide, resulting in the potential augmentation of global warming. Although there is significant evidence that increased UV-B exposure is harmful to aquatic organisms, damage to ecosystems is still uncertain. One of the most important concepts for assessing the impacts of enhanced levels of UV-B exposure on aquatic ecosystems is that complex rather than simple responses are likely to be the rule. Responses will not be limited to simple decreases in primary production. In fact, shifts in community structure may initially be more common and result in small detectable differences in ecosystem biomass.

\section{References}

[1] USEPA (US Environmental Protection Agency), An assessment of the effects of ultraviolet-B radiation on aquatic organisms, in:
Assessing the Risks of Trace Gases That Can Modify the Stratosphere, EPA 400/1-87/001C, 1987, pp. 1-33.

[2] R.C. Smith, B.B. Prézelin, K.S. Baker, R.R. Bidigare, N.P. Boucher, T. Coley, D. Karentz, S. MacIntyre, H.A. Matlick, D. Menzies, M. Ondrusek, Z. Wan, K.J. Waters, Ozone depletion: ultraviolet radiation and phytoplankton biology in Antarctic waters, Science 255 (1992) 952-959.

[3] N.M. Scully, D.R.S. Lean, The attenuation of ultraviolet radiation in temperate lakes, in: C.E. Williamson, H.E. Zagarese (Eds.), Advances in Limnology: Impact of UV-B Radiation on Pelagic Ecosystems, Archiv für Hydrobiologie Beiheft 43 (Special Issue), 1994, pp. 135-144.

[4] D.-P. Häder, Photo-ecology and environmental photobiology, in: W.M. Horspool, P.-S. Song (Eds.), CRC Handbook of Organic Photochemistry and Photobiology, CRC Press, Boca Raton, FL, 1995, pp. 1392-1401.

[5] C.R. Booth, J.H. Morrow, T.P. Coohill, J.E. Frederick, D.-P. Häder, O. Holm-Hansen, W.H. Jeffrey, D.L. Mitchell, P.J. Neale, I. Sobolev, J. van der Leun, R.C. Worrest, Impacts of solar UVR on aquatic microorganisms, Photochem. Photobiol. 65 (1997) 252 269.

[6] T.P. Coohill, D.-P. Häder, D.L. Mitchell, Environmental ultraviolet photobiology: introduction, Photochem. Photobiol. 64 (1996) 401402.

[7] D.-P. Häder, R.C. Worrest, H.D. Kumar, R.C. Smith, Effects of increased solar ultraviolet radiation on aquatic ecosystems, Ambio 24 (1995) 174-180.

[8] S. Gerber, A. Biggs, D.-P. Häder, A polychromatic action spectrum for the inhibition of motility in the flagellate Euglena gracilis, Acta Protozoologica 35 (1996) 161-165.

[9] C. Jiménez, F.L. Figueroa, J. Aguilera, M. Lebert, D.-P. Häder, Phototaxis and gravitaxis in Dunaliella bardawil: influence of UV radiation, Acta Protozoologica 35 (1996) 287-295.

[10] D.-P. Häder, Effects of UV radiation on phytoplankton, in: J.G. Jones (Ed.), Advances in Microbial Ecology, vol. 15, Plenum, New York, 1997, pp. 1-26.

[11] D.-P. Häder, Effects of solar UV-B radiation on aquatic ecosystems, in: P.J. Lumsden (Ed.), Plants and UV-B: Responses to Environmental Change, Cambridge University Press, Cambridge, 1997, pp. 171-193.

[12] IASC, Effects of increased ultraviolet radiation in the Arctic, IASC Report No. 2, IASC Secretariat, J. Plant Physiol. 148 (1995) 4248 .

[13] D.-P. Häder, Stratospheric ozone depletion and increase in ultraviolet radiation, in: D.-P. Häder (Ed.), The Effects of Ozone Depletion on Aquatic Ecosystems, ch. 1, Environmental Intelligence Unit, Academic Press and R.G. Landes Company, Austin, 1997, pp. 14.

[14] D.-P. Häder, R.C. Worrest, Consequences of the effects of increased solar ultraviolet radiation on aquatic ecosystems, in: D.-P. Häder (Ed.), The Effects of Ozone Depletion on Aquatic Ecosystems, ch. 3, Environmental Intelligence Unit, Academic Press and R.G. Landes Company, Austin, TX, 1997, pp. 11-30.

[15] H.W. Ducklow, C.A. Carlson, N.R. Bates, A.H. Knap, A.F. Michaels, Dissolved organic carbon as a component of the biological pump in the North Atlantic Ocean, Philos. Trans. Roy. Soc. London B: Biol. Sci. 348 (1995) 161-167.

[16] T. Takahashi, T.T. Takahashi, S. Sutherland, An assessment of the role of the North Atlantic as a $\mathrm{CO}_{2}$ sink, Philos. Trans. Roy. Soc. London B: Biol. Sci. 348 (1995) 143-152.

[17] T. Takahashi, R.A. Feely, R.F. Weiss, R.H. Wanninkhof, D.W. Chipman, S.C. Sutherland, T. Takahashi, Global air-sea flux of $\mathrm{CO}_{2}$ : an estimate based on measurements of sea-air $\mathrm{pCO}_{2}$ difference, Proc. Natl. Acad. Sci. USA 94 (1997) 8282-8299.

[18] J.L. Sarmiento, C. Le Quéré, Oceanic carbon dioxide uptake in a model of century-scale global warming, Science 274 (1996) 13461350 . 
[19] D.J. Thomson, Dependence of global temperatures on atmospheric $\mathrm{CO}_{2}$ and solar irradiance, Proc. Natl. Acad. Sci. USA 94 (1997) 8370-8377.

[20] C.V. Nolan, G.T. Amanatidis, European Commission research on the fluxes and effects of environmental UVB radiation, J. Photochem. Photobiol. B: Biol. 31 (1995) 3-7.

[21] D.-P. Häder, UV-B and aquatic ecosystems, in: J. Rozema, W.W.C. Gieskes, S.C. van de Geijn, C. Nolan, H. de Boois (Eds.), UV-B and Biosphere, Kluwer, Dordrecht, 1997, pp. 4-13.

[22] W.C. Dunlap, J.M. Shick, Ultraviolet radiation-absorbing mycosporine-like amino acids in coral reef organisms: a biochemical and environmental perspective, J. Phycol. 34 (1998) 418-430.

[23] J.J. Cullen, P.J. Neale, Biological weighting functions for describing the effects of ultraviolet radiation on aquatic systems, in: D-P. Häder (Ed.), The Effects of Ozone Depletion on Aquatic Ecosystems, ch. 6, Environmental Intelligence Unit, Academic Press and R.G Landes Company, Austin, TX, 1997, pp. 97-118.

[24] J.J. Cullen, P.J. Neale, Effects of ultraviolet radiation on short-term photosynthesis of natural phytoplankton, Photochem. Photobiol. 65 (1997) 264-266.

[25] L.A. Franklin, R.M. Forster, The changing irradiance environment: consequences for marine macrophyte physiology, productivity and ecology, Eur. J. Phycol. 32 (1997) 207-232.

[26] D.-P. Häder, F.L. Figueroa, Photoecophysiology of marine macroalgae, Photochem. Photobiol. 66 (1997) 1-14.

[27] J.M. Shick, M.P. Lesser, P.L. Jokiel, Effects of ultraviolet radiation on corals and other coral reef organisms, Global Change Biology 2 (1996) 527-545.

[28] M. Lesser, Acclimation of phytoplankton to UV-B radiation: oxidative stress and photoinhibition of photosynthesis are not prevented by UV-absorbing compounds in the dinoflagellate Prorocentrum micans, Marine Ecol. Progr. Ser. 132 (1996) 287 297 (correction: Marine Ecol. Progr. Ser. 141 (1996) 312).

[29] C.E. Williamson, Effects of UV radiation on freshwater ecosystems, Int. J. Environment. Studies 51 (1996) 245-256.

[30] T. Naganuma, S. Konishi, T. Inoue, T. Nakane, S. Sukizaki, Photodegradation or photoalteration? Microbial assay of the effect of UV-B on dissolved organic matter, Marine Ecol. Progr. Ser. 135 (1996) 309-310.

[31] R.G. Wetzel, P.G. Hatcher, T.S. Bianchi, Natural photolysis by ultraviolet irradiance of recalcitrant dissolved organic matter to simple substrates for rapid bacterial metabolism, Limnol. Oceanogr. 40 (1995) 1369-1380.

[32] G.J. Herndl, Role of ultraviolet radiation on bacterioplankton activity, in: D.-P. Häder (Ed.), The Effects of Ozone Depletion on Aquatic Ecosystems, ch. 8, Environmental Intelligence Unit, Academic Press and R.G. Landes Company, Austin, TX, 1997, pp. $143-$ 154.

[33] V. Montecino, G. Pizarro, Phytoplankton acclimation and spectral penetration of UV irradiance off the central Chilean coast, Marine Ecol. Progr. Ser. 121 (1995) 261-269.

[34] L.O. Björn, A. Cunningham, Z. Dubinsky, M. Estrada, F.L. Figueroa, F. Garcia-Pichel, D.-P. Häder, D. Hanelt, G. Levavasseur, K. Lüning, Technical discussion, I: underwater light measurements and light absorption by algae, in: F.L. Figueroa, C. Jiménez, J.L. Pérez-Lloréns, F.X. Niell (Eds.), Underwater Light and Algal Photobiology, Scientia Marina 60 (Suppl. 1), Barcelona, Spain, 1996, pp. 59-63

[35] N.G. Jerlov, Optical Oceanography, Elsevier, Amsterdam, 1968.

[36] H. Piazena, D.-P. Häder, Penetration of solar UV and PAR into different waters of the Baltic Sea and remote sensing of phytoplankton, in: D.-P. Häder (Ed.), The Effects of Ozone Depletion on Aquatic Ecosystems, ch. 5, Environmental Intelligence Unit, Academic Press and R.G. Landes Company, Austin, TX, 1997, pp. 4596.

[37] J.H. Morrow, C.R. Booth, Instrumentation and methodology for ultraviolet radiation measurements in aquatic environments, in: D.-
P. Häder (Ed.), The Effects of Ozone Depletion on Aquatic Ecosystems, ch. 4, Environmental Intelligence Unit, Academic Press and R.G. Landes Company, Austin, TX, 1997, pp. 31-44.

[38] F.L. Figueroa, F. Gimenez-Gomez, M.L. Villarino, J. Rodriguez, F.G. Figueiras, Underwater light and phytoplankton distribution during a daily cycle in the Ria of Vigo (NW Spain), Sci. Mat. 58 (1994) 119-130.

[39] R. Santas, A. Koussoulaki, D.-P. Häder, In assessing biological UVB effects, natural fluctuations of solar radiation should be taken into account, Plant Ecology 128 (1997) 93-97.

[40] G. Seckmeyer, S. Thiel, M. Blumthaler, P. Fabian, S. Gerber, A. Gugg-Helminger, D.-P. Häder, M. Huber, C. Kettner, U. Köhler, P. Köpke, H. Maier, J. Schäfer, P. Suppan, E. Tamm, E. Thomalla, Intercomparison of spectral-UV-radiation measurement systems, Appl. Optics 33 (1994) 7805-7812.

[41] H. Ott, G.T. Amanatides, Sesame 1994-1995: a European contribution to the stratospheric ozone issue, DG XII, EC, Brussels, 1994, p. 16

[42] J. Zeng, K. Stamnes, Impact of stratospheric ozone depletion on UV penetration into the ocean, 1994 Ocean Sciences Meet., San Diego, CA, 21-25 Feb., 1994

[43] C.W. Brown, W.E. Esaias, A.M. Thompson, Predicting phytoplankton composition from space - using the ratio of euphotic depth to mixed-layer depth: an evaluation, Remote Sensing Environment 53 (1995) 172-176.

[44] K.J. Waters, R.C. Smith, Phytoplankton production in the Sargasso Sea as determined using optical mooring data, J. Geophys. Res. 99 (1994) 18385-18402.

[45] A. Meinesz, T. Belscher, C.-F. Bouderesque, J.-R. Lefevre, Première évaluation des potentialés du satellite Spot pour la cartographie des peuplements benthiques superficieles de Méditerranée occidentale, Oceanologica Acta 14 (1991) 299-307.

[46] M.J. Behrenfeld, P.G. Falkowski, Photosynthetic rates derived from satellite-based chlorophyll concentration, Limnol. Oceanogr. 42 (1997) 1-20.

[47] M.J. Behrenfeld, P.G. Falkowski, A consumer's guide to phytoplankton primary productivity models, Limnol. Oceanogr. 42 (1997) 1479-1491.

[48] J.A. Fuhrman, R.T. Noble, Viruses and protists cause similar bacterial mortality in coastal seawater, Limnol. Oceanogr. 40 (1995) $1236-1242$.

[49] L.R. Pomeroy, W.J. Wiebe, Energetics of microbial food webs, Hydrobiologia 159 (1988) 7-18.

[50] D. Karentz, M.L. Bothwell, R.B. Coffin, A. Hanson, G.J. Herndl, S.S. Kilham, M.P. Lesser, M. Lindell, R.E. Moeller, D.P. Morris, P.J. Neale, R.W. Sanders, C.S. Weiler, R.G. Wetzel, Report of working group on bacteria and phytoplankton, in: C.E. Williamson, H.E. Zagarese (Eds.), Impact of UV-B Radiation on Pelagic Freshwater Ecosystems, Archiv für Hydrobiologie Beiheft 43 (Special Issue), 1994, pp. 31-69.

[51] F. Garcia-Pichel, A model for the internal self-shading in planktonic organisms and its implications for the usefulness of ultraviolet sunscreens, Limnol. Oceanogr. 39 (1994) 1704-1717.

[52] W.H. Jeffrey, P. Aas, M. Maille Lyons, R.B. Coffin, R.J. Pledger, D.L. Mitchell, Ambient solar radiation-induced photodamage in marine bacterioplankton, Photochem. Photobiol. 64 (1996) 419427.

[53] W.H. Jeffrey, R.J. Pledger, P. Aas, S. Hager, R.B. Coffin, R.V. Haven, D.L. Mitchell, Diel and depth profiles of DNA photodamage in bacterioplankton exposed to ambient solar ultraviolet radiation, Marine Ecol. Progr. Ser. 137 (1996) 283-291.

[54] W.L. Nicholson, Photoreactivation in the genus Bacillus, Current Microbiol. 31 (1995) 361-365.

[55] G. Müller-Niklas, A. Heissenberger, S. Puskaric, G.J. Herndl, Ultraviolet-B radiation and bacterial metabolism in coastal waters, Aquat. Microbial Ecol. 9 (1995) 111-116. 
[56] P. Aas, M. Lyons, R. Pledger, D.L. Mitchell, W.H. Jeffrey, Inhibition of bacterial activities by solar radiation in nearshore waters and the Gulf of Mexico, Aquat. Microbial Ecol. 11 (1996) 229-238.

[57] R. Sommaruga, M. Krössbacher, W. Salvenmoser, J. Catalan, R. Psenner, Presence of large virus-like particles in a eutrophic reservoir, Aquat. Microbial Ecol. 9 (1995) 305-308.

[58] R. Sommaruga, A. Oberleiter, R. Psenner, Effect of UV radiation on the bacterivory of a heterotrophic nanoflagellate, Appl. Environment. Microbiol. 62 (1996) 4395-4400.

[59] R.P. Sinha, D.-P. Häder, Impacts of UV-B irradiation on rice-field cyanobacteria, in: D.-P. Häder (Ed.), The Effects of Ozone Depletion on Aquatic Ecosystems, ch. 9, Environmental Intelligence Unit, Academic Press and R.G. Landes Company, Austin, TX, 1997, pp. 189-198.

[60] A.K. Kashyap, K.D. Pandey, R.K. Gupta, Nitrogenase activity of the Antarctic cyanobacterium Nostoc commune: influence of temperature, Folia Microbiologica 36 (1991) 557-560.

[61] R.P. Sinha, N. Singh, A. Kumar, H.D. Kumar, M. Häder, D.-P Häder, Effects of UV irradiation on certain physiological and biochemical processes in cyanobacteria, J. Photochem. Photobiol. B Biol. 32 (1996) 107-113.

[62] R.P. Sinha, D.-P. Häder, Photobiology and ecophysiology of rice field cyanobacteria, Photochem. Photobiol. 64 (1996) 887-896.

[63] A. Kumar, M.B. Tyagi, G. Srinivas, N. Singh, H.D. Kumar, R.P Sinha, D.-P. Häder, UVB shielding role of $\mathrm{FeCl}_{3}$ and certain cyanobacterial pigments, Photochem. Photobiol. 64 (1996) 321-325.

[64] M. Banerjee, D.-P. Häder, Effects of UV radiation on the rice field cyanobacterium Aulosira fertilissima, Environment. Exp. Botany 36 (1996) 281-291.

[65] V.A. Donkor, D.-P. Häder, Effects of ultraviolet irradiation on photosynthetic pigments in some filamentous cyanobacteria, Aquat. Microbial Ecol. 11 (1996) 143-149.

[66] V.A. Donkor, D.-P. Häder, Ultraviolet radiation effects on pigmentation in the cyanobacterium Phormidium uncinatum, Acta Protozoologica 36 (1997) 49-55

[67] R.P. Sinha, H.D. Kumar, A. Kumar, D.-P. Häder, Effects of UV-B irradiation on growth, survival, pigmentation and nitrogen metabolism enzymes in cyanobacteria, Acta Protozoologica 34 (1995) 187-192.

[68] R. Aráoz, D.-P. Häder, Ultraviolet radiation induces both degradation and synthesis of phycobilisomes in Nostoc sp.: a spectroscopic and biochemical approach, FEMS Microbiol. Ecol. 23 (1997) 301313 .

[69] A. Kumar, R.P. Sinha, D.-P. Häder, Effect of UV-B on enzymes of nitrogen metabolism in the cyanobacteria Nostoc calcicola, J. Plant Physiol. 148 (1996) 86-91.

[70] W.F. Vincent, S. Roy, Solar ultraviolet radiation and aquatic primary production: damage, protection and recovery, Environment Revs. 1 (1993) 1-12.

[71] V.A. Donkor, D.-P. Häder, Protective strategies of several cyanobacteria against solar radiation, J. Plant Physiol. 145 (1995) 750755 .

[72] U. Karsten, F. Garcia-Pichel, Carotenoids and mycosporine-like amino acid compounds in members of the Genus Microcoleus (Cyanobacteria): a chemosystematic study, System. Appl. Microbiol. 19 (1996) 285-294.

[73] R.C. Smith, J.J. Cullen, Effects of UV radiation on phytoplankton, Rev. Geophys. Suppl. (1995) 1211-1223.

[74] M. Vernet, R.C. Smith, Effects of ultraviolet radiation on the pelagic Antarctic ecosystem, in: D-P. Häder (Ed.), The effects of Ozone Depletion on Aquatic Ecosystems, ch. 16, Environmental Intelligence Unit, Academic Press and R.G. Landes Company, Austin, TX, 1997, pp. 247-265.

[75] J.J. Cullen, P.J. Neale, Effects of ultraviolet radiation on short-term photosynthesis of natural phytoplankton, Photochem. Photobiol. 65 (1996) 264-266.
[76] N.P. Boucher, B.B. Prezelin, An in situ biological weighting function for UV inhibition of phytoplankton carbon fixation in the Southern Ocean, Marine Ecol. Progr. Ser. 114 (1996) 223-236.

[77] P.J. Neale, J.J. Cullen, R.F. Davis, Inhibition of marine photosynthesis by ultraviolet radiation: variable sensitivity of phytoplankton in the Weddell-Scotia Sea during austral spring, Limnol. Oceanogr. 43 (1998) 433-488.

[78] K.R. Arrigo, Impact of ozone depletion on phytoplankton growth in the Southern Ocean: large-scale spatial and temporal variability, Marine Ecol. Progr. Ser. 114 (1994) 1-12.

[79] J.J. Cullen, P.J. Neale, Ultraviolet radiation, ozone depletion, and marine photosynthesis, Photosynth. Res. 39 (1994) 303-320.

[80] M.L. Bothwell, D.M.J. Sherbot, C.M. Pollock, Ecosystem response to solar ultraviolet-B radiation: influence of trophic level interactions, Science 256 (1994) 97-100.

[81] O. Holm-Hansen, Short- and long-term effects of UVA and UVB on marine phytoplankton productivity, Photochem. Photobiol. 65 (1997) 266-268.

[82] I.R. Vassiliev, O. Prasil, K.D. Wyman, Z.K. Kolber, A.K. Hanson, J.E. Prentice, P.G. Falkowski, Inhibition of PS II photochemistry by PAR and UV radiation in natural phytoplankton communities, Photosynth. Res. 42 (1994) 51-64.

[83] H. Herrmann, D.-P. Häder, M. Köfferlein, H.K. Seidlitz, F. Ghetti, Study on the effects of UV radiation on phytoplankton photosynthetic efficiency by means of a sunlight simulator, Med. Biol. Environ. 23 (1995) 36-40.

[84] H. Herrmann, D.-P. Häder, M. Köfferlein, H.K. Seidlitz, F. Ghetti, Effects of UV radiation on photosynthesis of phytoplankton exposed to solar simulator light, J. Photochem. Photobiol. B: Biol. 34 (1996) 21-28.

[85] H. Herrmann, D.-P. Häder, F. Ghetti, Inhibition of photosynthesis by solar radiation in Dunaliella salina: relative efficiencies of UVB, UV-A and PAR, Plant, Cell Environ. 20 (1997) 359-365.

[86] G.M. Giacometti, R. Barbato, S. Chiaramonte, G. Friso, F. Rigoni, Effects of ultraviolet-B radiation on photosystem II of the cyanobacterium Synechocystis sp. PCC 6083, Eur. J. Biochem. 242 (1996) 799-806

[87] F.L. Figueroa, C. Jiménez, L.M. Lubián, O. Montero, M. Lebert, D.-P. Häder, Effects of high irradiance and temperature on photosynthesis and photoinhibition in Nannochloropsis gaditana Lubián (Eustigmatophyceae), J. Plant Physiol. 151 (1997) 6-15.

[88] W.W.C. Gieskes, A.G.J. Buma, UV damage to plant life in a photobiologically dynamic environment: the case of marine phytoplankton, Plant Ecology 128 (1997) 16-25.

[89] S. Gerber, D.-P. Häder, Effects of enhanced solar irradiance on chlorophyll fluorescence and photosynthetic oxygen production of five species of phytoplankton, FEMS Microbiol. Ecol. 16 (1995) 33-42.

[90] S. Gerber, D.-P. Häder, Effects of artificial and simulated solar radiation on the flagellate Euglena gracilis: physiological, spectroscopical and biochemical investigations, Acta Protozoologica 34 (1995) 13-20.

[91] A.G.J. Buma, H.J. Zemmelink, K. Sjollema, W.W.C. Gieskes, UVB radiation modifies protein and photosynthetic pigment content, volume and ultrastructure of marine diatoms, Marine Ecol. Progr. Ser. 147 (1996) 47-54

[92] H. Peletier, W.W.C. Gieskes, A.G.J. Buma, Ultraviolet-B radiation resistance of benthic diatoms isolated from tidal flats in the Dutch Wadden Sea, Marine Ecol. Progr. Ser. 135 (1996) 163-168.

[93] M.J. Behrenfeld, Ultraviolet-B radiation effects on inorganic nitrogen uptake by natural assemblages of oceanic plankton, J. Phycol. 31 (1995) 25-36.

[94] G. Döhler, Effect of UV irradiance on utilization of inorganic nitrogen by the Antarctic diatom Odontella weissflogii (Janisch) Grunow, Botanica Acta 109 (1996) 35-42.

[95] G. Döhler, Impact of UV radiation of different wavebands on pigments and assimilation of ${ }^{15} \mathrm{~N}$-ammonium and ${ }^{15} \mathrm{~N}$-nitrate by natural 
phytoplankton and ice algae in Antarctica, J. Plant Physiol. 151 (1997) 550-555.

[96] G. Döhler, E. Hagmeier, UV-effects on pigments and assimilation of ${ }^{15} \mathrm{~N}$-ammonium and ${ }^{15} \mathrm{~N}$-nitrate by natural marine phytoplankton of the North Sea, Botanica Acta 110 (1997) 481-488.

[97] G. Döhler, E. Hagmeier, C. David, Effects of solar and artificial UV irradiation on pigments and assimilation of ${ }^{15} \mathrm{~N}$ ammonium and ${ }^{15} \mathrm{~N}$ nitrate by macroalgae, J. Photochem. Photobiol. B: Biol. 30 (1995) 179-187.

[98] R. Scheuerlein, S. Treml, B. Thar, U.K. Tirlapur, D.-P. Häder, Evidence for UV-B-induced DNA degradation in Euglena gracilis mediated by activation of metal-dependent nucleases, J. Photochem. Photobiol. B: Biol. 31 (1995) 113-123.

[99] A.G.J. Buma, E.J. van Hannen, L. Roza, M.J.W. Veldhuis, W.W.C. Gieskes, Monitoring ultraviolet-B-induced DNA damage in individual diatom cells by immunofluorescent thymine dimer detection, J. Phycol. 51 (1995) 314-321.

[100] A.G.J. Buma, E.J. van Hannen, M.J.W. Veldhuis, W.W.C. Gieskes, UV-B induces DNA damage and DNA synthesis delay in the marine diatom Cyclotella sp., Scientia Marina 60 (Suppl. 1), Barcelona, Spain, 1996, pp. 101-106.

[101] A.G.J. Buma, A.H. Engelen, W.W.C. Gieskes, Wavelengthdependent induction of thymine dimers and growth rate reduction in the marine diatom Cyclotella sp. exposed to ultraviolet radiation, Marine Ecol. Progr. Ser. 153 (1997) 91-97.

[102] R. Santas, D.-P. Häder, C. Lianou, Effects of solar UV radiation on diatom assemblages of the Mediterranean, Photochem. Photobiol. 64 (1996) 435-439.

[103] S.-Å. Wängberg, J.-S. Selmer, Studies of effects of UV-B radiation on aquatic model ecosystems, in: D.-P. Häder (Ed.), The Effects of Ozone Depletion on Aquatic Ecosystems, ch. 12, Environmental Intelligence Unit, Academic Press and R.G. Landes Company, Austin, TX, 1997, pp. 199-214.

[104] K. Lüning, Seaweeds. Their Environment, Biogeography and Ecophysiology, John Wiley, New York, 1990.

[105] D.-P. Häder, Penetration and effects of solar UV-B on phytoplankton and macroalgae, Plant Ecology 128 (1997) 4-13.

[106] S. Markager, K. Sand-Jensen, The physiology and ecology of lightgrown relationship in macroalgae, in: F.E. Round, D.J. Chapman (Eds.), Progress in Phycological Research, vol. 10, Biopress Ltd., Bristol, 1994, pp. 209-298.

[107] M.J. Dring, V. Makarov, E. Schoshina, M. Lorenz, K. Luning, Influence of ultraviolet radiation on chlorophyll fluorescence and growth in different life history stages of three species of Laminaria (Phaeophyta), Marine Biol. 126 (1996) 183-191.

[108] C. Wiencke, I. Bartsch, B. Bischoff, A.F. Peters, A.M. Breeman, Temperature requirements and biogeography of Antarctic, Arctic and amphiequatorial seaweeds, Botanica Marina 37 (1994) 247259.

[109] F.L. Figueroa, C. Jiménez, J.L. Pérez-Lloréns, F.X. Niell, Underwater light and algal photobiology, Scientia Marina 60 (Suppl. 1), Barcelona, Spain, 1996, pp. 343.

[110] K.S. Beach, C.M. Smith, Ecophysiology of tropical rhodophytes. I. Microscale acclimation in pigmentation, J. Phycol. 32 (1996) 701710 .

[111] K.S. Beach, C.M. Smith, Ecophysiology of tropical rhodophytes. II. Microscale acclimation in photosynthesis, J. Phycol. 32 (1996) $710-718$.

[112] G.O. Kirst, C. Wiencke, Ecophysiology of algae, J. Phycol. 31 (1996) 181-199.

[113] M. Porst, H. Herrmann, J. Schäfer, R. Santas, D.-P. Häder, Photoinhibition in the Mediterranean green alga Acetabularia mediterranea measured in the field under solar irradiation, J. Plant Physiol. 151 (1997) 25-32.

[114] D.-P. Häder, J. Schäfer, In-situ measurement of photosynthetic oxygen production in the water column, Environment. Monitoring Assessment 32 (1994) 259-268.
[115] U. Schreiber, U. Schliwa, W. Bilger, Continuous recording of photochemical and non-photochemical chlorophyll fluorescence quenching with a new type of modulation fluorometer, Photosynth. Res. 10 (1986) 51-62.

[116] H. Herrmann, F. Ghetti, R. Scheuerlein, D.-P. Häder, Photosynthetic oxygen and fluorescence measurements in Ulva laetevirens affected by solar irradiation, J. Plant Physiol. 145 (1995) 221-227.

[117] C. Büchel, C. Wilhelm, In vivo analysis of slow chlorophyll fluorescence induction kinetics in algae: progress, problems and perspectives, Photochem. Photobiol. 58 (1993) 137-148.

[118] B. Demmig-Adams, W. Adams III, Photoprotection and other responses of plants to high light stress, Ann. Revs. Plant Physiol. Plant Molec. Biol. 43 (1992) 599-626.

[119] C. Critchley, A.W. Russell, Photoinhibition of photosynthesis in vivo: the role of protein turnover in photosystem II, Physiologia Plantarum 92 (1994) 188-196.

[120] D. Hanelt, M.J. Jaramillo, W. Nultsch, S. Senger, R. Westermeir, Photoinhibition as a regulatory mechanism of photosynthesis in marine algae of Antarctica, Serie Cient. Inst. Antarct., Chil. 44 (1994) 67-77.

[121] I. Gómez, C. Wiencke, G. Weykman, Seasonal photosynthetic characteristics of the brown alga Ascoseira mirabilis from King George Island (Antarctica), Marine Biol. 123 (1995) 167-172.

[122] C. Wiencke, Recent advances in the investigation of Antarctic macroalgae, Polar Biol. 16 (1996) 231-240.

[123] I. Gómez, C. Wiencke, Photosynthesis, dark respiration and pigment contents of gametophytes and sporophytes of the Antarctic brown alga Desmarestia menziessi, Botanica Marina 39 (1996) 149-157.

[124] R. Foster, K. Lüning, Photosynthetic response of Laminaria digitata to ultraviolet A and B radiation, in: F.L. Figueroa, C. Jiménez, J.L. Pérez-Lloréns (Eds.), Underwater Light and Algal Photobiology, Scientia Marina 60 (Suppl. 1), Barcelona, Spain, 1996, pp. 65-71.

[125] J.M. Mercado, C. Jiménez, F.C.X. Niell, F.L. Figueroa, Comparisons of methods for measuring light absorption by algae and their application to the estimation of the package effect, in: F.L. Figueroa, C. Jiménez, J.L. Pérez-Lloréns (Eds.), Underwater Light and Algal Photobiology, Scientia Marina 60 (Suppl. 1), Barcelona, Spain, 1996, pp. 39-45.

[126] F. Garcia-Pichel, A scalar irradiance fiber-optic microprobe for the measurement of ultraviolet radiation at high spatial resolution, Photochem. Photobiol. 61 (1995) 248-254.

[127] H. Schubert, B.M.A. Kroon, H.C.P. Matthijs, In vivo manipulation of the xanthophyll cycle and the role of the zeaxanthin cycle in the photoprotection against photodamage in the green alga Chlorella pyrenoidosa, J. Biol. Chem. 269 (1994) 7267-7272.

[128] C. Grevby, Organisation of the light harvesting complex in fucoxanthin containing algae, Ph.D. Thesis, Göteborg University, Sweden, 1996.

[129] S. Uhrmacher, D. Hanelt, W. Nultsch, Zeaxanthin content and the degree of photoinhibition are linearly correlated in the brown alga Dictyota dichotoma, Marine Biol. 123 (1995) 159-165.

[130] L.A. Franklin, G.G.R. Seaton, C.E. Lovelock, A.D.W. Larkum, Photoinhibition of photosynthesis on a coral reef, plant cell environ. 19 (1996) 825-836.

[131] P.R. Leavitt, R.D. Vinebrooke, D.B. Donald, J.P. Smol, D.W. Schindler, Past ultraviolet radiation environments in lakes derived from fossil pigments, Nature 388 (1997) 457-459.

[132] K. Banse, Zooplankton: pivotal role in the control of ocean production, ICES J. Marine Sci. 52 (1995) 265-277.

[133] D.M. Damkaer, Possible influence of solar UV radiation in the evolution of marine zooplankton, in: J. Calkins (Ed.), The Role of Solar Ultraviolet Radiation in Marine Ecosystems, Plenum, New York, 1982, pp. 701-706.

[134] J.H.M. Kouwenberg, H.I. Browman, J.A. Runge, J.J. Cullen, R.F. Davis, J.-F. St-Pierre, Biological weighting of ultraviolet (280-400 $\mathrm{nm}$ ) induced mortality in marine zooplankton and fish II, Calanus finmarchicus G. (Copepoda) eggs, Marine Biol. 1998, in press. 
[135] D. Roemmich, J. McGowan, Climatic warming and the decline of zooplankton in the California Current, Science 267 (1995) 1324 1326.

[136] K.D. Malloy, M.A. Holman, D. Mitchell, H.W. Detrich III, Solar UVB-induced DNA damage and photoenzymatic DNA repair in Antarctic zooplankton, Proc. Natl. Acad. Sci. USA 94 (1997) $1258-1263$.

[137] T. Naganuma, T. Inoue, S. Uye, Photoreactivation of UV-induced damage to embryos of a planktonic copepod, J. Plankton Res. 19 (1997) 783-787.

[138] L. Chalker-Scott, Survival and sex ratios of the intertidal copepod, Tigriopus californicus, following ultraviolet-B $(290-320 \mathrm{~nm})$ radiation exposure, Marine Biol. 123 (1995) 799-804.

[139] D. Karentz, F.S. McEuen, M.C. Land, W.C. Dunlap, Survey of microsporine-like amino acid compounds in Antarctic marine organisms: potential protection from ultraviolet exposure, Marine Biol. 108 (1991) 157-166.

[140] B.E. Brown, R.P. Dunne, T.P. Scoffin, M.D.A. le Tissier, Solar damage in intertidal corals, Marine Ecol. Progr. Ser. 105 (1994) 219-230.

[141] D.F. Gleason, G.M. Wellington, Variation in UVB sensitivity of planula larvae of the coral Agaricia agaricites along a depth gradient, Marine Biol. 123 (1995) 693-703.

[142] A.K. Caroll, J.M. Shick, Dietary accumulation of UV-Absorbing mycosporine-like amino acids (MAAs) by the green sea urchin (Strongylocentrotus droebachiensis), Marine Biol. 124 (1996) 561-569.

[143] P.M. Vitousek, H.A. Mooney, J. Lubchenco, J.M. Melillo, Human domination of Earth's ecosystems, Science 277 (1997) 494-499.

[144] FAO Yearbook of Fishery Statistics — Catches and Landings, 1995, http://www.fao.org/waicent/faoinfo/fishery/trends/catch/ globalsf.htm

[145] R. Holmes, Biologists sort the lessons of fisheries collapse, Science 264 (1994) 1252-1253

[146] B.J. Rothchild, How bountiful are ocean fisheries?, Consequences 2 (1996) 26-36.

[147] J.R. Hunter, S.E. Kaupp, J.H. Taylor, Assessment of effects of UV radiation on marine fish larvae, in: J. Calkins (Ed.), The Role of Solar Ultraviolet Radiation in Marine Ecosystems, Plenum, New York, 1982, pp. 459-497.

[148] E.E. Little, D.L. Fabacher, Comparative sensitivity of rainbow trout and two threatened salmonids, Appache Trout and Lahontan Cutthroat Trout, to UV-B radiation, Archiv für Hydrobiologie Beiheft 43 (1994) 217-226.

[149] J.H.M. Kouwenberg, H.I. Browman, J.J. Cullen, R.F. Davis, J.-F. St-Pierre, J.A. Runge, Biological weighting of ultraviolet (280-400 $\mathrm{nm}$ ) induced mortality in marine zooplankton and fish I, Atlantic cod (Gadus morhua L) eggs, Marine Biol. 1998, in press.

[150] C.E. Williamson, S.L. Metzgar, P.A. Lovera, R.E. Moeller, Solar ultraviolet radiation and the spawning habitat of yellow perch, Perca flavescens, Ecolog. Appl. 7 (1997) 1017-1023.

[151] D.B. Wake, Declining amphibian populations, Science 253 (1991) 860.

[152] J.B. Hays, A.R. Blaustein, J.M. Kiesecker, P.D. Hoffman, I. Pandelova, D. Coyle, T. Richardson, Developmental responses of amphibians to solar and artificial UVB sources: a comparative study, Photochem. Photobiol. 64 (1996) 449-456.

[153] A.R. Blaustein, J.M. Kiesecker, The effects of ultraviolet-B radiation on amphibians in natural ecosystems, in: D.-P. Häder, (Ed.), The Effects of Ozone Depletion on Aquatic Ecosystems, Environemntal Intelligence Unit, ch. 10, Academic Press and R.G. Landes Company, Austin, TX, 1997, pp. 175-188.

[154] R.C. Worrest, D.J. Kimeldorf, Distortions in amphibian development induced by ultraviolet-B enhancement (290-315 nm) of a simulated solar spectrum, Photochem. Photobiol. 24 (1976) 377 382.
[155] A.R. Blaustein, J.M. Kiesecker, D.P. Chivers, R.G. Anthony, Ambient UV-B radiation causes deformities in amphibian embryos, Proc. Natl. Acad. Sci. USA 94 (1997) 13735-13737.

[156] L.E. Licht, K.P. Grant, The effects of ultraviolet radiation on the biology of amphibians, Amer. Zoologist 37 (1997) 137-145

[157] K. Ovaska, T.M. Davis, I.N. Flamarique, Hatching success and larval survival of the frogs Hyla regilla and Rana aurora under ambient and artificially enhanced solar ultraviolet radiation, Can. J. Zool. 75 (1997) 1081-1088.

[158] P.S. Corn, Effects of ultraviolet radiation on boreal toads in Colorado, Ecolog. Appl. 8 (1998) 18-26.

[159] G.T. Ankley, J.E. Tiegte, D.L. DeFoe, K.M. Jensen, G.W. Holcombe, E.S. Durhan, S.A. Diamond, Effects of ultraviolet radiation and methoprene on survival and development of Rana pipiens, Environment. Toxicol. Chem. 17 (1998) in press.

[160] L.C. Rai, B. Tyagi, N. Mallick, Alternation in photosynthetic characteristics of Anabaena dolium following exposure to UV-B and $\mathrm{Pb}$, Photochem. Photobiol. 64 (1996) 658-663.

[161] B.J.F. Biggs, Patterns in benthic algae of streams, in: R.J. Stevenson (Ed.), Algal Ecology, Academic Press, San Diego, CA, 1996, pp. 31-56.

[162] C.E. Williamson, What role does UV-B radiation play in freshwater ecosystems?, Limnol. Oceanogr. 40 (1995) 386-392.

[163] M. Häder, D.-P. Häder, Optical properties and phytoplankton composition in a freshwater ecosystem (Main-Donau-Canal), in: D.-P Häder (Ed.), The Effects of Ozone Depletion on Aquatic Ecosystems, ch. 9, Environmental Intelligence Unit, Academic Press and R.G. Landes Company, Austin, TX, 1997, pp. 155-174.

[164] P.K. Rai, L.C. Rai, Interactive effects of UV-B and Cu on photosynthesis, uptake and metabolism of nutrients in green alga Chlorella vulgaris and simulated ozone column, J. Gen. Appl. Microbiol. 43 (1997) in press.

[165] F. Xiong, F. Lederer, J. Lukavsky, L. Nedbal, Screening of freshwater algae (Chlorophyta, Chromophyta) for ultraviolet-B sensitivity of the photosynthetic apparatus, J. Plant Physiol. 148 (1996) 42-48.

[166] S. Halac, M. Felip, L. Camarero, S. Sommaruga-Wögrath, R. Psenner, J. Catalan, R. Sommaruga, An in situ enclosure experiment to test the solar UVB impact on plankton in a high-altitude mountain lake. I, Lack of effect on phytoplankton species composition and growth, J. Plankton Res. 19 (1997) 1671-1686.

[167] D.S. Kim, Y. Watanabe, Inhibition of growth and photosynthesis of freshwater phytoplankton by ultraviolet A (UVA) radiation and subsequent recovery from stress, J. Plankton Res. 16 (1994) 16451654

[168] A. Quesada, Growth of Antarctica cyanobacteria under ultraviolet radiation: UVA counteracts UVB inhibition, J. Phycol. 31 (1995) 242-248

[169] R. Sommaruga, R.D. Robarts, The significance of autotrophic and heterotrophic picoplankton in hypertrophic ecosystems, FEMS Microbiol. Ecol. 24 (1997) 187-200.

[170] C.W. Sullivan, K.R. Arrigo, C.R. McClain, J.C. Comiso, J. Firestone, Distributions of phytoplankton blooms in the Southern Ocean, Science 262 (1993) 1832-1837.

[171] R.C. Smith, K.S. Baker, M.L. Byers, S.E. Stammerjohn, Primary productivity of the Palmer Long-Term Ecological Research Area and the Southern Ocean, J. Marine Syst. 529 (1998) in press.

[172] D. Karentz, H.J. Spero, Response of a natural Phaeocystis population to ambient fluctuations of UVB radiation caused by Antarctic ozone depletion, J. Plankton Res. 17 (1995) 1771-1789.

[173] A.T. Davidson, H.J. Marchant, W.K. de la Mare, Natural UV exposure changes the species composition of Antarctic phytoplankton in mixed culture, Aquatic Microbial Ecol. 10 (1996) 299-305.

[174] P.J. Neale, R.F. Davis, J.J. Cullen, Interactive effects of ozone depletion and vertical mixing on photosynthesis of Antarctic phytoplankton, Nature 392 (1998) 585-589. 
[175] V.E. Villafañe, W.W. Helbling, O. Holm-Hansen, B.E. Chalker, Acclimatization of Antarctic natural phytoplankton assemblages when exposed to solar ultraviolet radiation, J. Plankton Res. 17 (1995) 2295-2306.

[176] E.B. Helbling, B.E. Chalker, W.C. Dunlap, O. Holm-Hansen, V.E. Villafañe, Photoacclimation of Antarctic marine diatoms to solar ultraviolet radiation, J. Exp. Marine Biol. Ecol. 204 (1996) 85101.

[177] M.J. Behrenfeld, H. Lee II, L.F. Small, Interactions between nutritional status and long-term responses to ultraviolet-B radiation stress in a marine diatom, Marine Biol. 118 (1994) 523-530.

[178] E.W. Helbling, V. Villafañe, O. Holm-Hansen, Effects of ultraviolet radiation on Antarctic marine phytoplankton photosynthesis with particular attention to the influence of mixing, in: C.S. Weiler, P.A. Penhale (Eds.), Ultraviolet Radiation in Antarctica: Measurements and Biological Effects, Antarctic Research Series \#62, American Geophysical Union, Washington, DC, 1994, pp. 207-227.

[179] M. Vernet, E.A. Brody, O. Holm-Hansen, B.G. Mitchell, The response of Antarctic phytoplankton to ultraviolet radiation: absorption, photosynthesis, and taxonomic composition, in: C.S. Weiler, P.A. Penhale (Eds.), Ultraviolet Radiation in Antarctica: Measurements and Biological Effects, Antarctic Research Series \#62,
American Geophysical Union, Washington, DC, 1994, pp. 143158.

[180] C.S. Weiler, P.A. Penhale, Ultraviolet Radiation in Antarctica: Measurements and Biological Effects, American Geophysical Union, Washington, DC, 1994.

[181] S.-Å. Wängberg, J.S. Selmer, N.G.A. Ekelund, K. Gustavson, UVB effects on Nordic marine ecosystems, TemaNord, Nordic Council of Ministers, Denmark, 1996, p. 515.

[182] V.I. Burenkov, Optical properties of the Laptev Sea near the Lena River delta, Proc. Symp. High Latitude Optics, Tromso, Norway, 1993, 28 June-2 July, 1993

[183] A.M. Springer, C.P. McRoy, The paradox of pelagic food webs in the northern Bering Sea. III. Patterns of primary production, Continental Shelf Res. 13 (1993) 575-599.

[184] V. Milot-Roy, W.F. Vincent, UV radiation effects on photosynthesis: the importance of near-surface thermoclines in a subarctic lake, in: C.E. Williamson, H.E. Zagarese (Eds.), Advances in Limnology: Impact of UV-B radiation on Pelagic Ecosystems, Archiv für Hydrobiologie Beiheft 43 (Special Issue), 1994, pp. 171-184.

[185] G. Döhler, Impact of UV-B radiation (290-320 nm) on uptake of ${ }^{15} \mathrm{~N}$-ammonia and ${ }^{15} \mathrm{~N}$-nitrate by phytoplankton of the Wadden Sea, Marine Biol. 112 (1992) 485-489. 